Journal of Educational

and Psychological Sciences

Volume (6), Issue (9) : 28 Feb 2022

P: 1 - 22

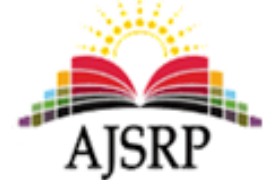

ISSN: 2522-3399

$$
\begin{aligned}
& \text { مجلة العلوم } \\
& \text { التربوية والنفسية } \\
& \text { المجلد (6)، العدد (9) : } 28 \text { فبراير } 2022 \text { م } \\
& \text { ص: } 1 \text { - } 22
\end{aligned}
$$

\title{
Administrative and technical obstacles of school principals in the Directorate of Education in the North Western Badia District and their proposals to address them
}

\author{
Afaf Nasser Sauh Shawaqfeh \\ Ministry of Education || Jordan
}

\begin{abstract}
The study aimed to identify the reality of administrative and technical obstacles to school principals in the Directorate of Education for the North West Badia and their suggestions to address them and to achieve the objectives of the study, the descriptive approach was used, and the tool was a survey of (35) paragraph, which has been distributed to a sample 130) principal ; The results showed that the degree of obstacles on the community as a whole had an average (4.16 of 5) and at the field of areas; The fields on students received at the top of the average (4.41) and the constraints of the technological equipment for the school at average (4.39) and the obstacles to the implementation of the curriculum at an average (4.25) and all of which is a verbal estimate (very large); Constraints relating to the local community (3.97) and fifth; Constraints on teachers with average (3.76) and two of the last two verbal assessment (large), and the results have no statistically significant differences at a significant level $(0.05=\alpha)$ is attributed to the impact of gender in all areas and in total level, except for the constraints of teachers and the differences in favor of male, There are statistically significant differences for the impact of scientific qualifications in all fields. According to the results, the researcher recommended the participation of staff and entities in the face of administrative and technical constraints through the use of their views, to find ways to facilitate and overcome them.
\end{abstract}

Keywords: obstacles, school principals, Western Badia.

$$
\begin{aligned}
& \text { المعوقات الإدارية والفنيّة لدى مديري المدارس في مديرية التربية والتعليم بلواء البادية } \\
& \text { الشمالية الغربية ومقترحاتهم لمعالجتها مدئه } \\
& \text { عفاف ناصبر سهو شـواقفه } \\
& \text { وزارة التربية التعليم || الأردن }
\end{aligned}
$$

\footnotetext{
المستخلص: هدفت الدّراسة للتعرف على واقع المعوقات الإدارية والفنيّة لدى مديري المدارس في مديرية التربية والتعليم للواء البادية

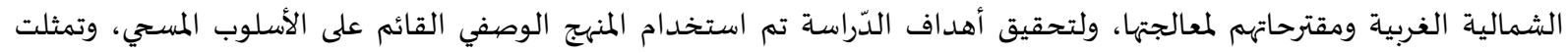

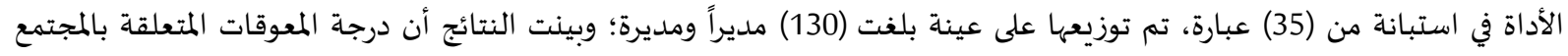

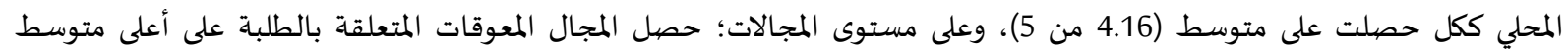

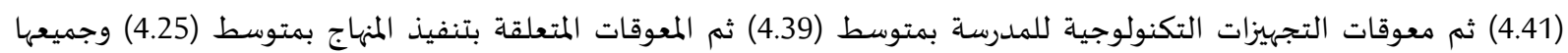

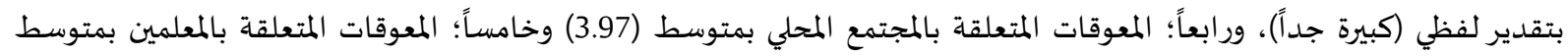

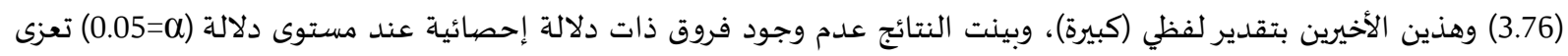

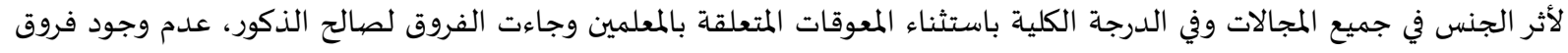


دلالة إحصائية تعزى لأثر المؤهل العلمي في جميع المجالات. واستنادا للنتائج أوصت الباحثة بالعمل على مشاركاتل الماركة الموظفين والجهات

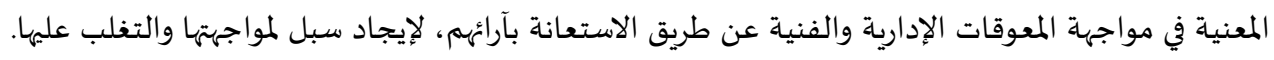

الكلمات المفتاحية: المعوقات الإداريّة والفنيّة، مديرو المدارس، البادية الشمالية الغربية.

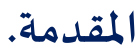

تحظى التربية بمكانة عظيمة في بناء الشخصية الإنسانية، فهي تهدف إلى استثمار التعليم من خلال إعداد

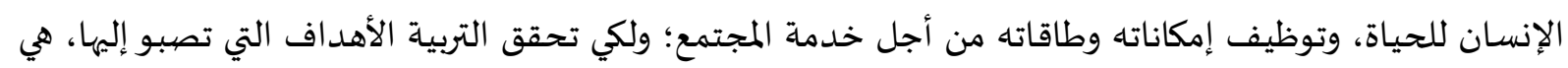
بحاجة ماسة إلى إدارة فعالة وهادفة ومتطورة.

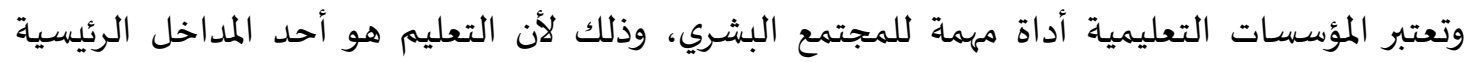

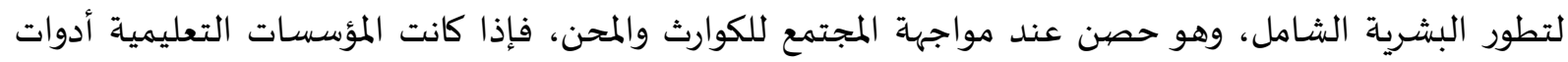

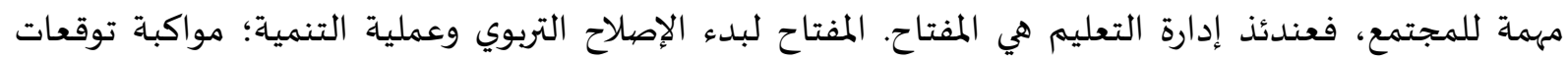
المجتمع (جمال الدين، 2013). تعد الإدارة المدرسية جزءا من الإدارة التربوية، وصورة مصغرة لتنظيماتها، حيث أن هناك ارتباطا وثيقا بينهما، فهما يدوران حول محور واحد هو التربية والتعليم، فالإدارة المدرسية تقوم بتنفيذ السياسة التعليمية، بينما تختص الإدارة التربوية برسم تلك السياسـة، ومساعدة الإدارة المدرسية ماليا وفنيا في تنفيذها، والإشراف عليهاف وليها

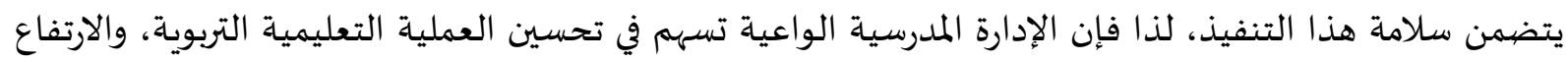
بمستوى الأداء، وذلك عن طريق توعية العاملين في المدرسة وتبصيرهم بمسؤولياتهم وتوجيههم التوجياه التربوي السليم(عطوي، 2010).

من هنا فإن الإدارة المدرسية عملية شاملة تستهدف إنجاز الأعمال المدرسية بفاعلية بواسطة العاملين في المدرسة، ولكن الرؤية الأصح تتجاوز كون الإدارة المدرسية مجرد عملية شاملة لتصبح منظومة شاملة متكاملة، "

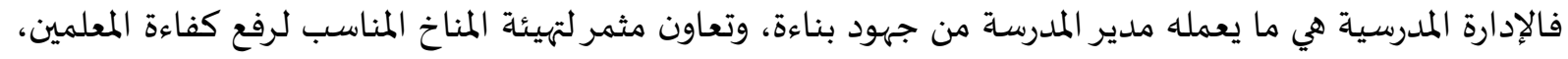

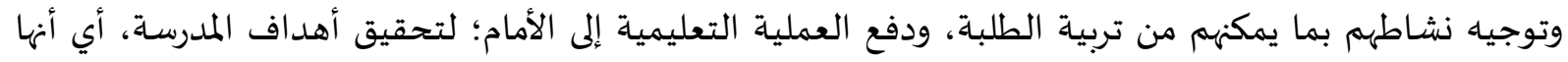

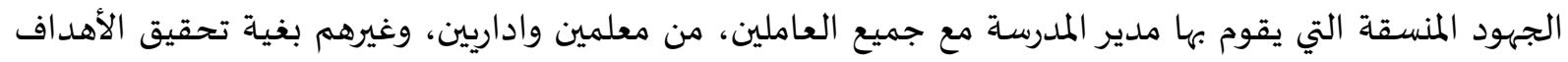

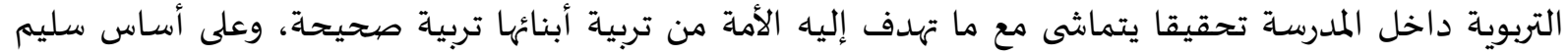

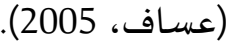

ففاعلية الإدارة المدرسية تتحدد بالدرجة الأولى بفاعلية مديرها، لأنه هو المحرك والموجه لكل العناصر والإمكانيات المتوفرة في المدرسة من أجل تحقيق الأهداف والطموحات والآمال في العمل المدرسي على ألمانه أكمل وجاه،

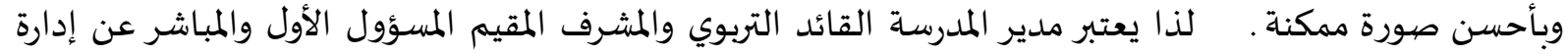

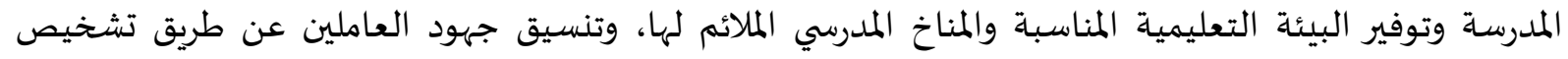

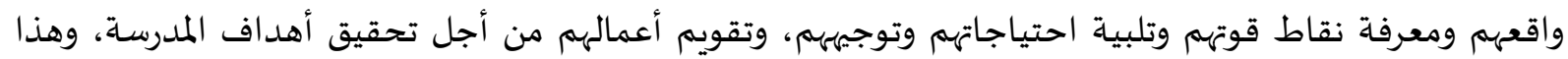

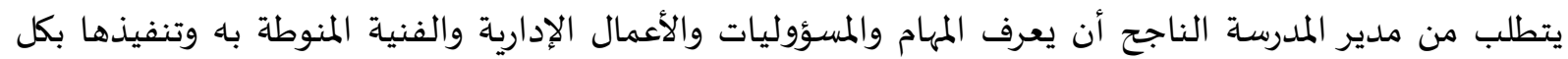
مهارة وفاعلية (عساف، 2005).

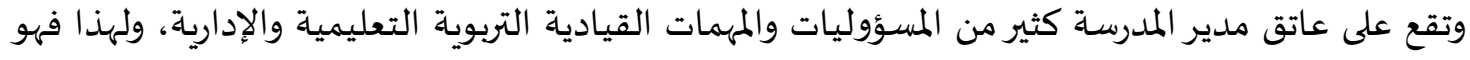
بحاجة إلى امتلاك كثير من أساليب الإشراف والتوجيه ونشاطاتهما؛ لكي يتمكن من أداء أدوراه ومهماته بنجاح 
وفاعلية، كون أن المعلمين الذين يقع عليهم فعل الإشراف والتوجيه يتفاوتون في خبراتهم وميولهم وحاجاتهم المهنية،

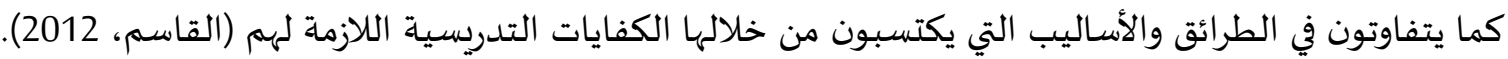

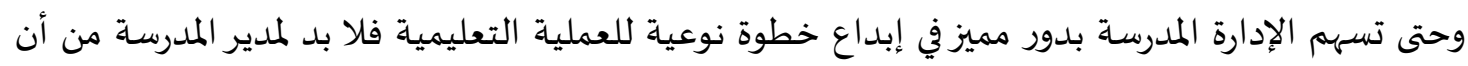

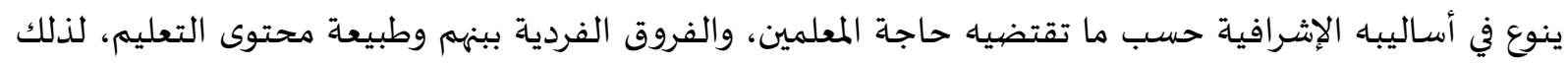

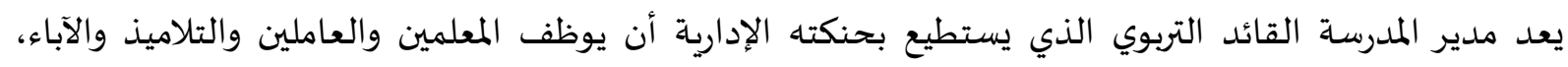

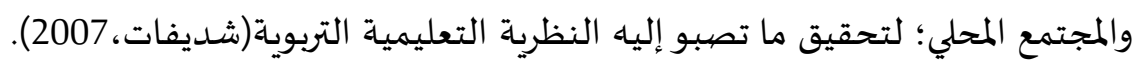

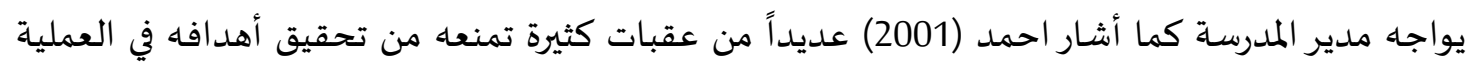

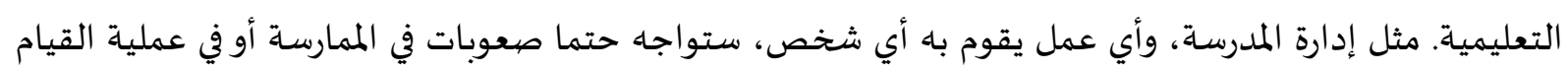

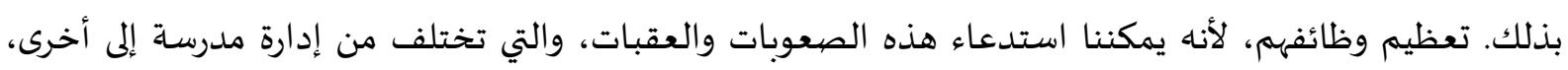

$$
\text { حسب ظروف المدرسة وطبيعة الشخص المسؤول. }
$$

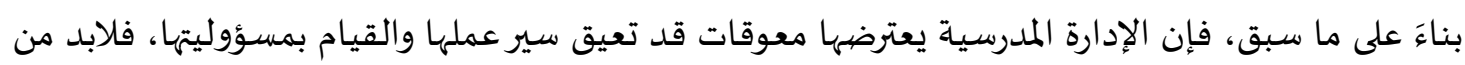

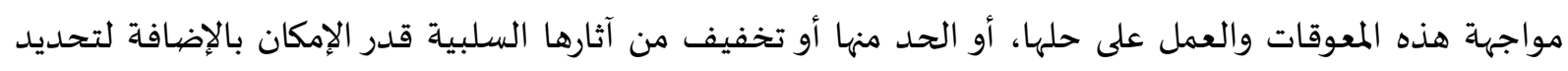

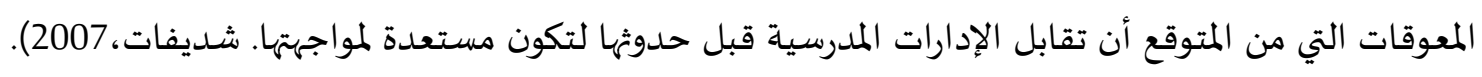

مشكلة الدّراسة:

تمر المملكة الأردنية الهاشمية بمرحلة تطوير وتحديث المناهج، والعمل على تطوير مهارات العاملين فهها، لأنّ النجاح يتوقف على قدرة هذه المدارس على التأقلم وبشكل مستمر مع التغيرات، ومن خلال قيام المدير بمهامه

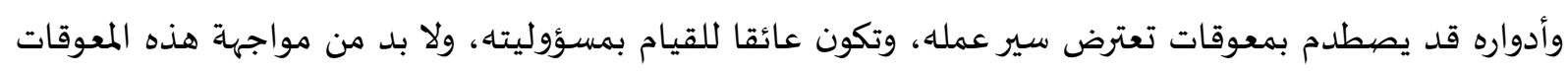

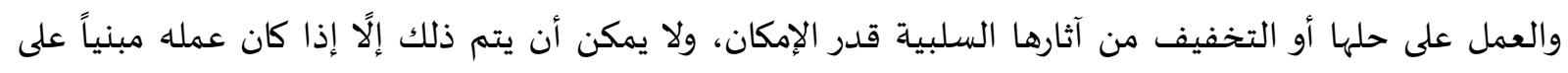

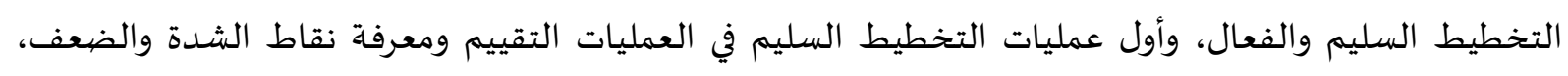
وتحديد هذه المعوقات التي قد تواجههم قبل أن يفاجئ بها، ومن ثم يكن مستعد لمواجهتها، ويكون لديه التصهور

المسبق لها وبكيفية حلها.

أسـئلة الدّراسـة:

وبناء على ما تقدم تتحدد مشكلة الدراسـة في الأسئلة التالية: 1- ما المعوقات الإدارية والفنيّة التي يواجهها مديرو المدارس في مديرية التربية والتعليم لمنطقة البادية الشمالية

الغربية؟ مابـ

2- هل توجد فروق ذات دلالة إحصائية عند مستوى الدلالة (20.05) حول المعوقات الإدارية والفنيّة التي

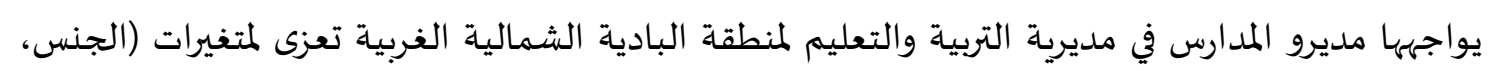

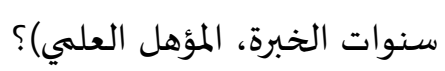
3- ما المقترحات لمعالجة المعوقات الإدارية والفنيّة التي يواجهها مديرو المدارس في مديرية التربية والتعليم

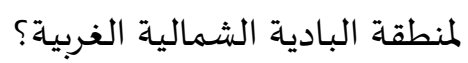
أهداف الدّراسة: تسعى الدّراسة إلى تحقيق الأهداف التالية: 
1. الكشف عن المعوقات الإدارية والفنيّة التي يواجهها مديرو المدارس في مديرية تربية لمنطقة البادية الشمالية

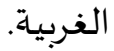

2. الكشف فيما إذا كان هناك فروق ذات دلالة إحصائية عند مستوى الدلالة (1<0.05) بين المعوقات الإدارية

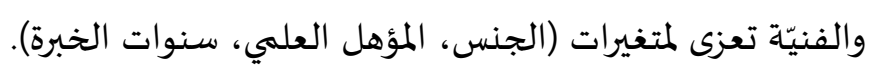

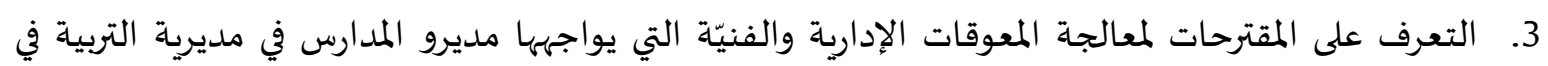
منطقة البادية الشمالية الغربية.

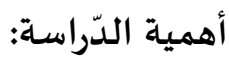
تنبثق أهمية الدّراسة من الأمور التالية: الأهمية النظرية: - تنبع أهمية هذا البحث من أهمية الدور المنوط بمدير المدرسة ومسؤولياته في مجال إدارة المدرسة وأثرها على إدارة التعليم والعملية التعليمية، وتواجه المدارس عقبات إدارية وفنية تساهم في تطوير العملية

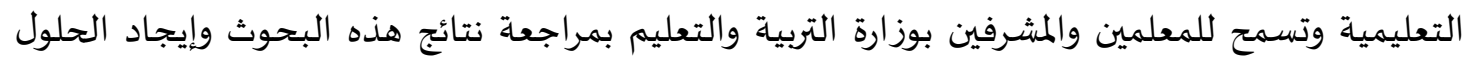
المناسبة واتخاذ القرارات المناسبة التي تخدم العملية التعليمية. الأهمية التطبيقية: - ـ قد تساعد هذا الدّراسة من خلال ما تسفر عنه من توصيات ومقترحات يستفيد منها القائمين على هذا

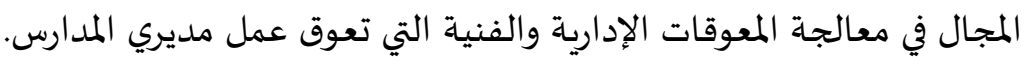

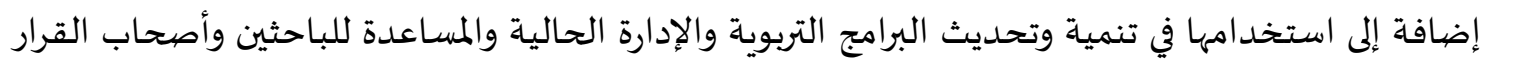

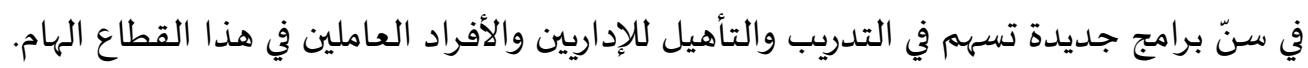

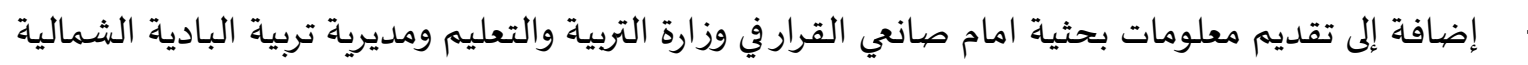

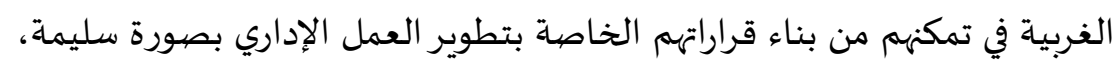

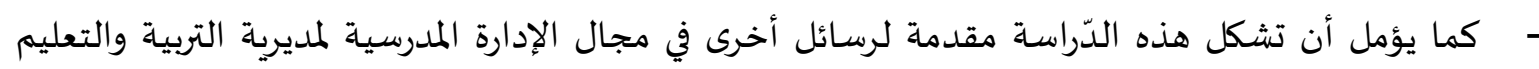

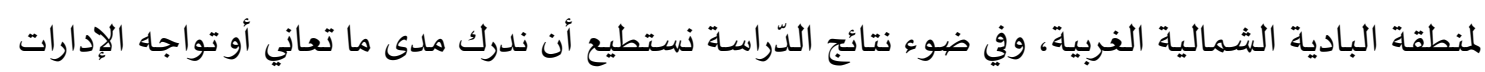

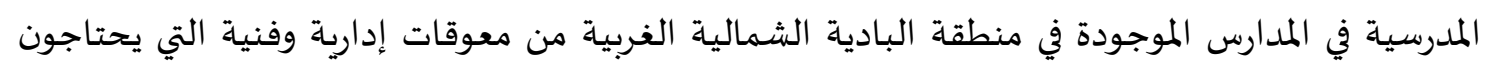
معها إلى من يأخذ بيدهم ويساعد هذه المعوقات والتخلص منها قدر المدرد الإمكان.

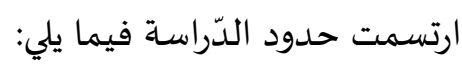
هالحدود الموضيوعية: المعوقات الإدارية والفنيّة التي تواجه الإدارة المدرسية (المدراء والمديرات). الحدود البشرية: مديري المدارس الحكومية والبالغ عددهم (130) مديراً ومديرة.

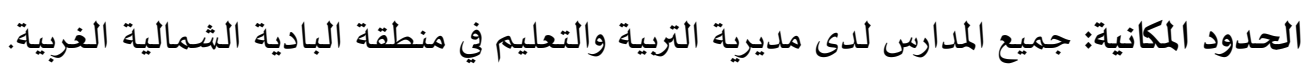
الحدود الزمانية: العام الدراسي (2021/2020) 
التعريفات الاصطلاحية والاجرائية

- الإدارة المدرسية اصطلاحاً: مجموعة النظريات التنفيذية والفنيّة التي تتم عن طريق العمل الجماعي التعاوني

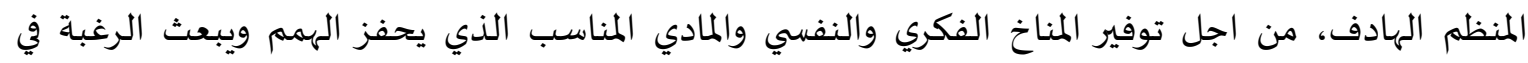

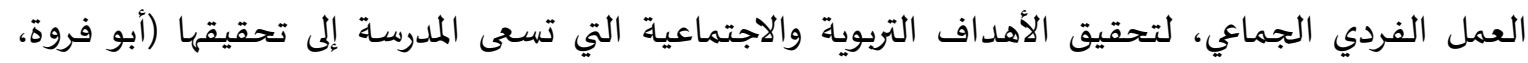

(1996

O وتعرف الإدارة المدرسية إجرائياً: مجموعة النظريات والخطط التي يقوم بها مدير المدرسة بغية الوصول بالمدرسة إلى أفضل مستوى من توفير الأهداف التربوية والإرشادية المدرية.

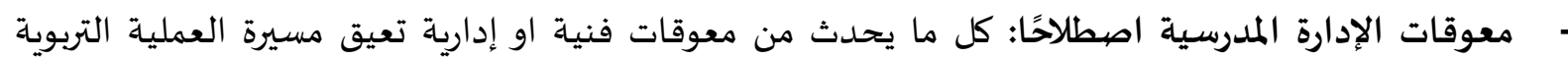
والتعليمية داخل المدرسة.

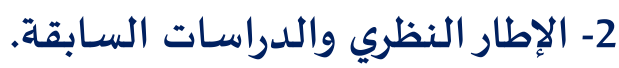

أولاً الإطار النظري

معوقات الإدارية والفنية المدرسية:

ان الإدارة المدرسية تعمل من أجل الوصول إلى اعلى مستوى من التعليم والفعالية، أن مسؤولية تدني

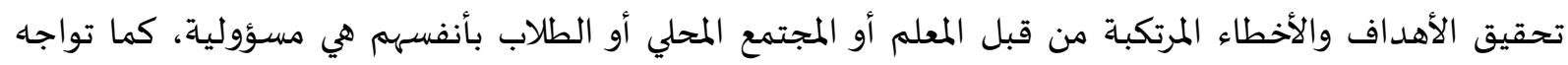

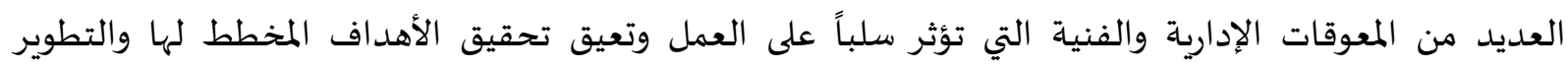

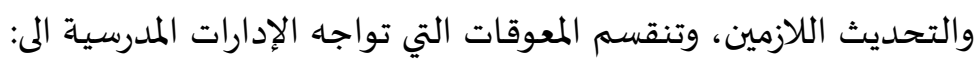

$$
\begin{aligned}
& \text { - معوقات إدارية - معوقات فنية - معوقات اجتماعية } \\
& \text { - معوقات شخصية - معوقات اقتصادية إداته معوفيه - معوفات }
\end{aligned}
$$

قام عايش (2013) بدراسة عن المعوقات الإدارية والفنية المدرسية تتمثل بكثرة الأعباء الفنية على المدير

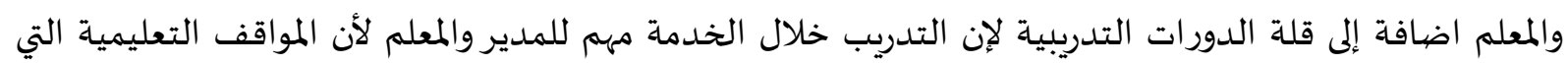

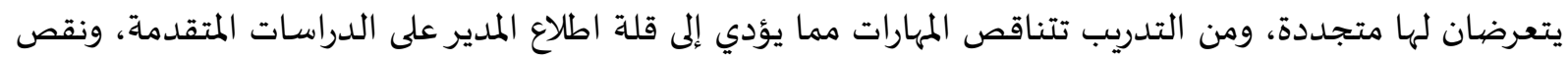

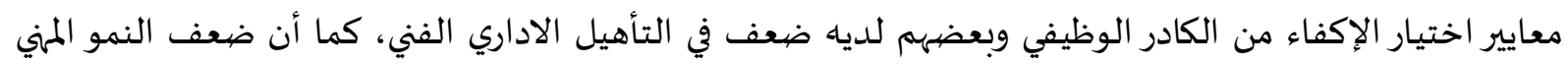
للمعلم هي من أكثر المشاكل التي تواجه الإدارة المدرسية.

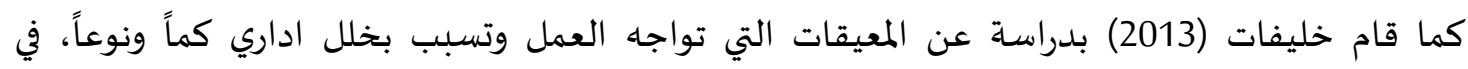
مجالات البحوث والدراسات العلمية والتخطيط الموجهة نحو الحاجات المجتمعية وتحسين الكفايات المات الادائية

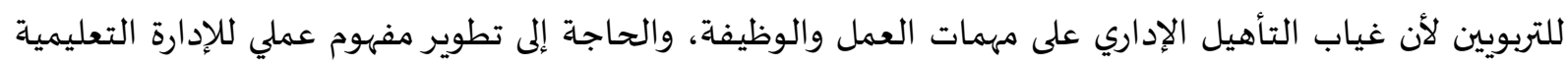
لأداء المهمات الازمة والمسؤوليات المتعلقة بالمدير بوصفه مشرفاً وقائداً هي من اكثر المعيقات الإنات الإدارية.

ثانياً- الدراسـات السابقة:

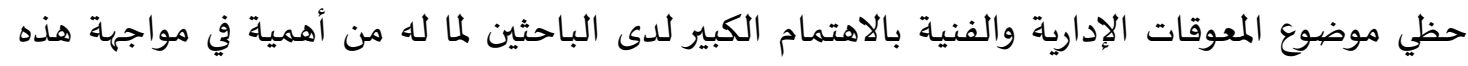

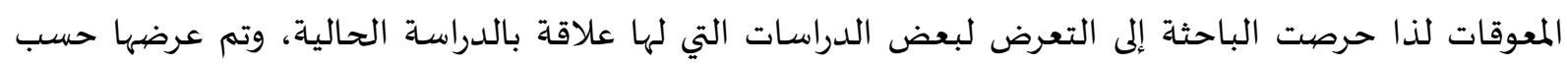

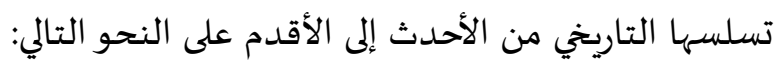


هدفت دراسة الخليفة، أبو ادريس (2019) إلى التعرف على مستوى وجود المعوقات ( الفنية والإدارية

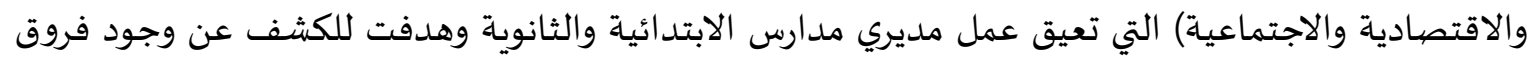

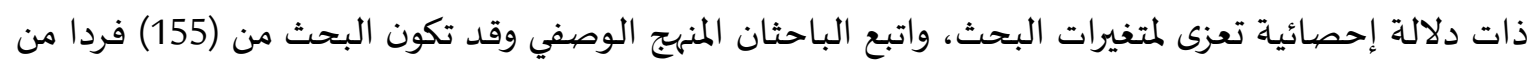

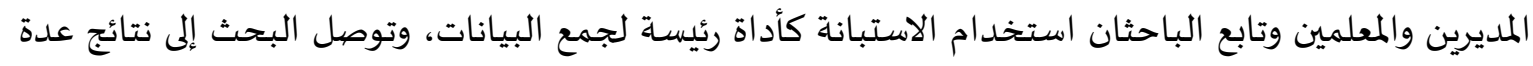

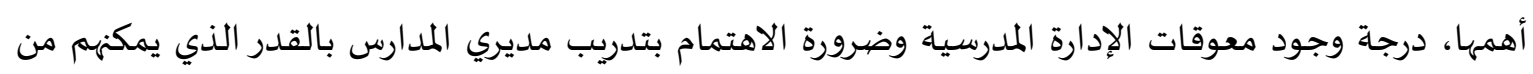
مواجهة معوقات العمل وإيجاد الحلول المناسبة في وقتها. دراسة الشمري والحربي (2019) وهدفت إلى التعرف على أهم المعوقات الإدارية التي تواجه مديري مدارس التهاد

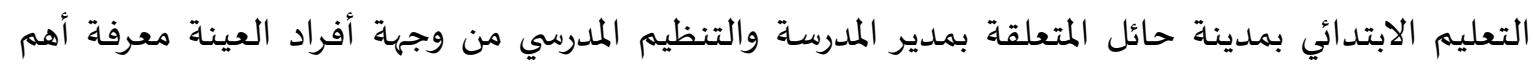

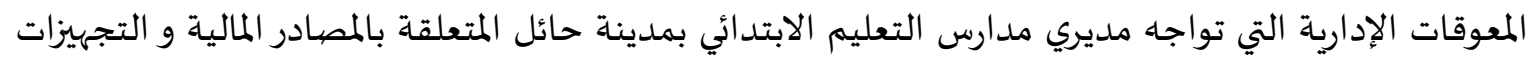

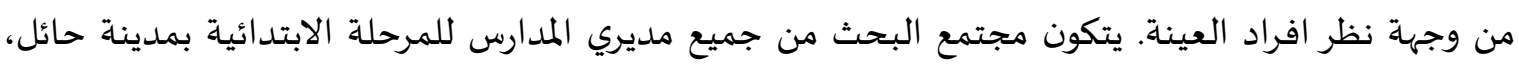

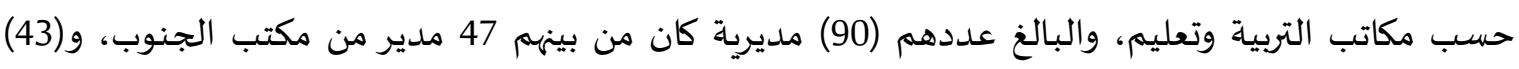

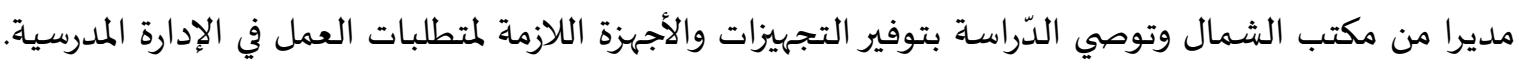

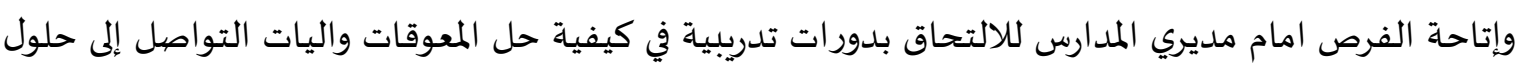

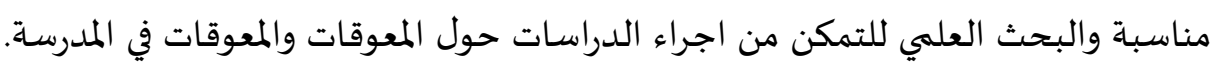
دراسة كناعنة وسلامة (2017) هدفت الدّراسة إلى التعرف على المعوقات التربوية التي تواجاه المدارس الثرات الثانوية

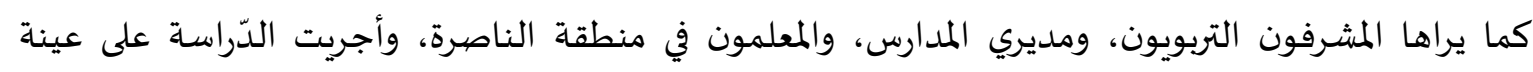

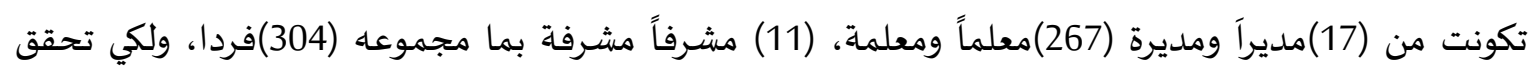

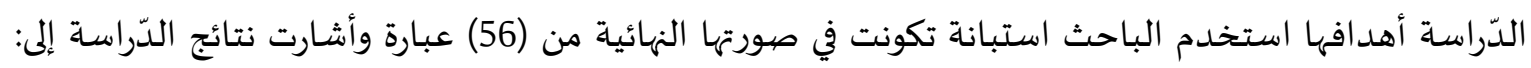

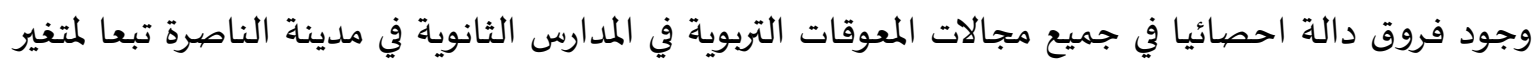

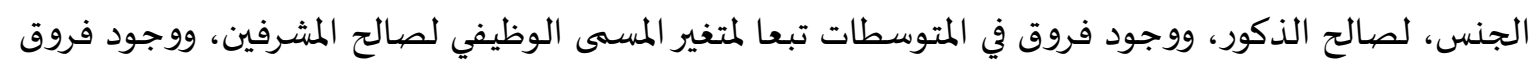

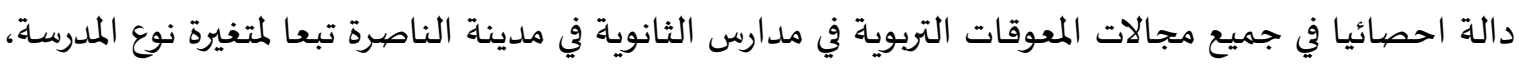

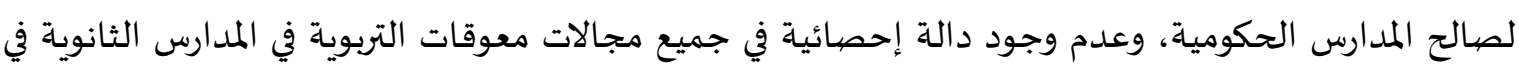
مدينة الناصرة تبعا لمتغيرة الخبرة.

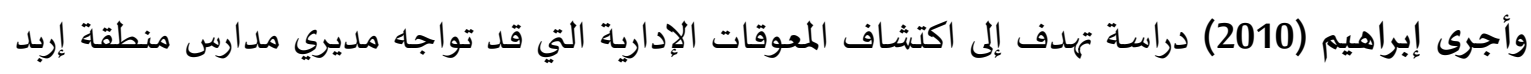

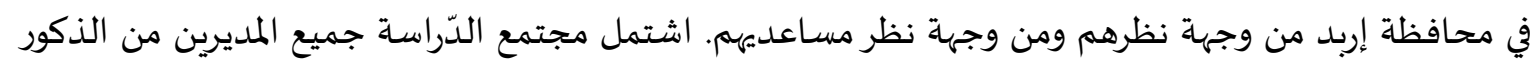

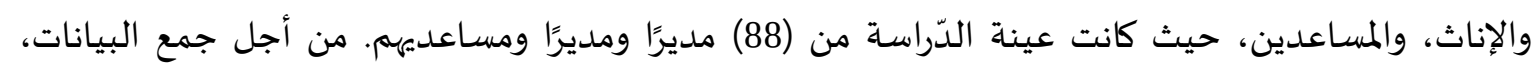

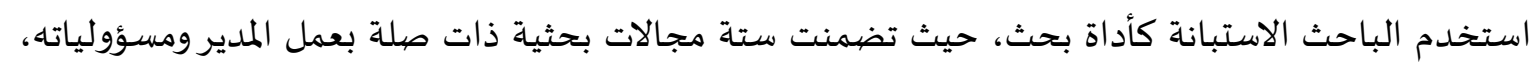

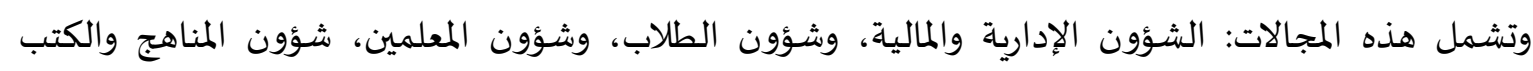

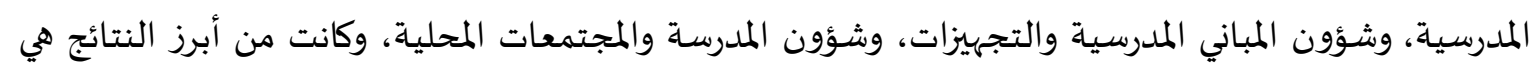

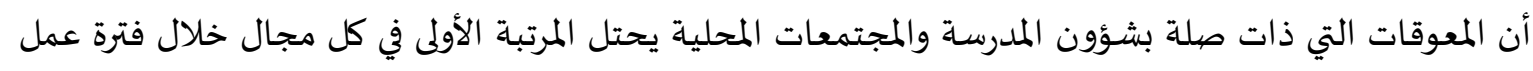

مديري المدارس. وأجرى أبو علي (2010) دراسة هدفت إلى التعرف على أهم القضايا المدرسية التي تؤثر على تطوير أداء المدير في

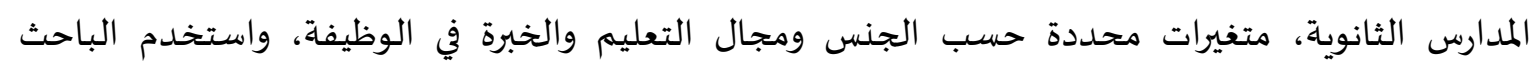
الاسلوب الوصفي، اشتمل مجتمع البحث جميع مديرات المدارس الثانوية (134) مديرة من أجل جمع البيانات، 
استخدم الباحث الاستبانة كأداة بحث وكان من أبرز النتائج هي أهم العوامل المؤثرة في تطوير أداء مديري

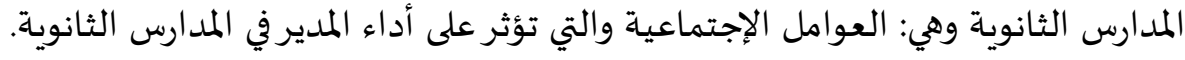

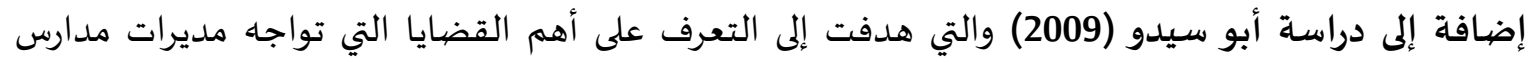

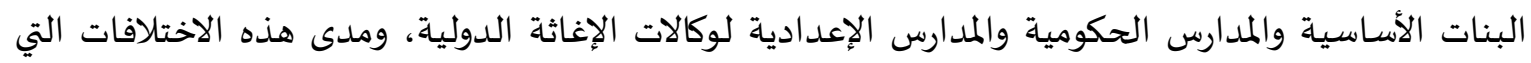

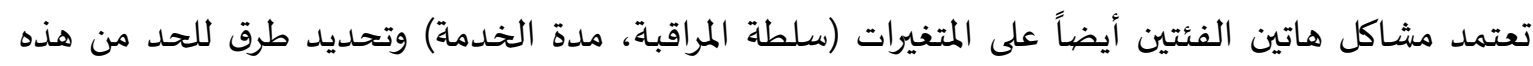

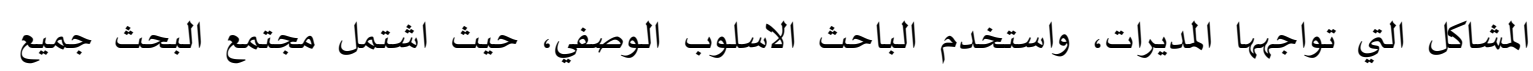

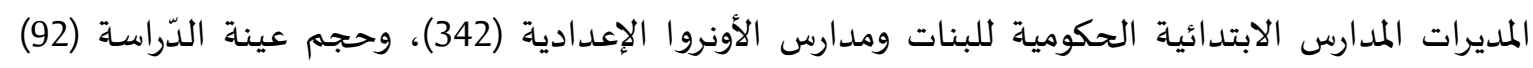

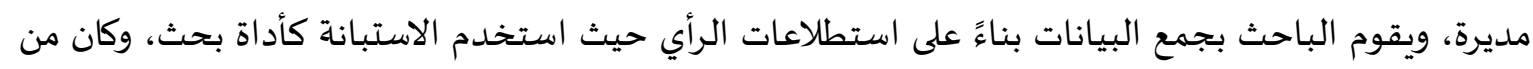

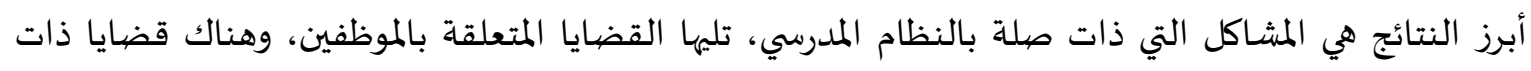

صلة بالإشراف التربوي. كما قام رضيوان (2009) بدراسـة تهدف إلى التعرف على أهم قضايا الإدارة المدرسية التي يواجهها مديري

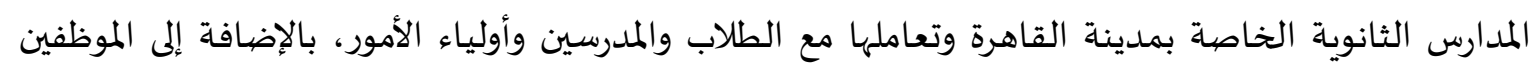

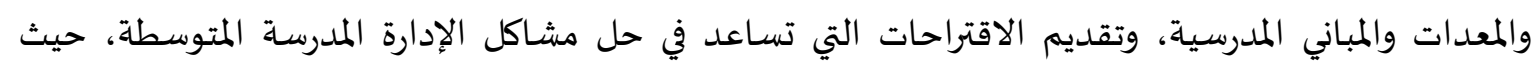

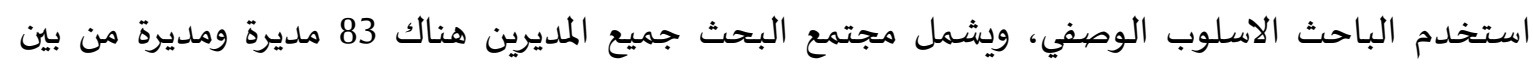

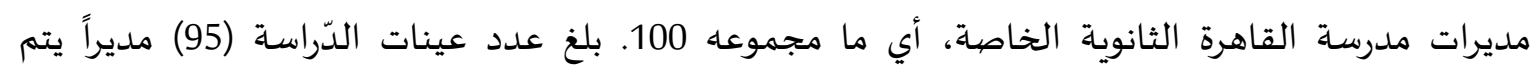

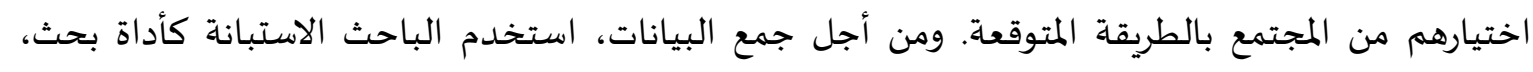

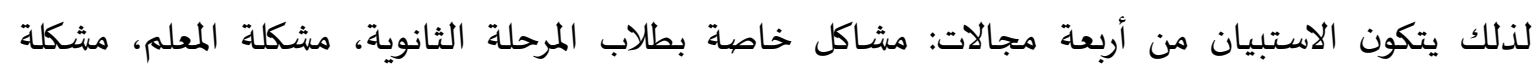

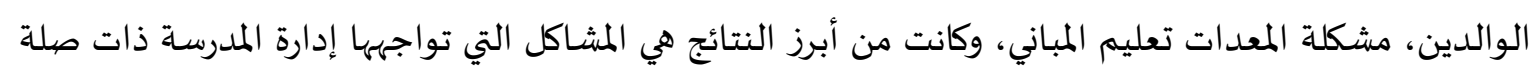

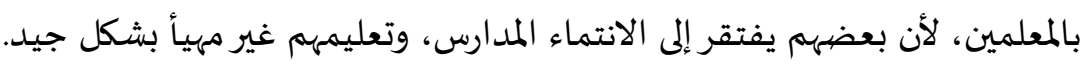

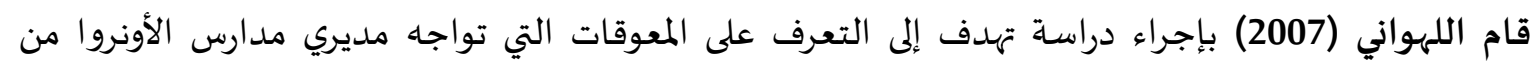

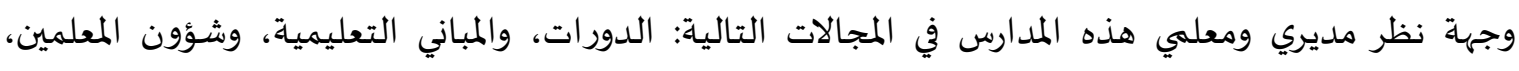

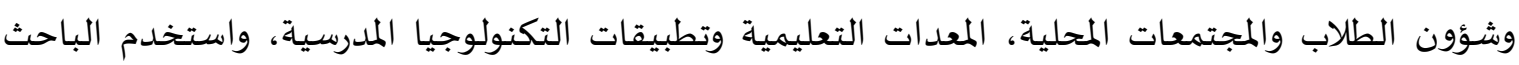

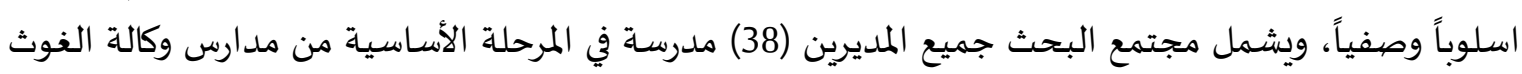

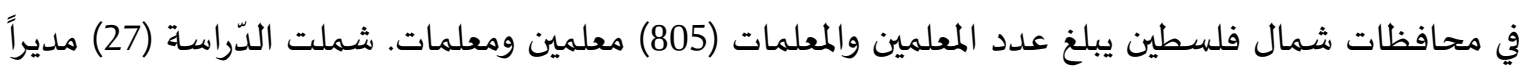

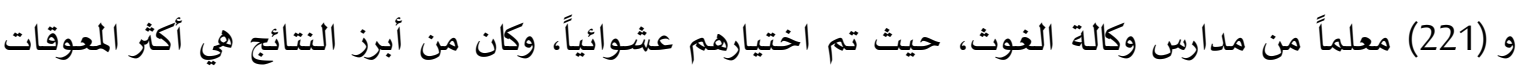
التي تواجه مديري المدارس هي الدورات التدريبية التي يحتاجها المعلمين قبل وأثناء الخدماء. وأجرت الصلوي (2005) دراسة هدفت إلى تحديد مدى خطورة المعوقات التي تواجه إدارة المدرسة في مرحلة فئلة

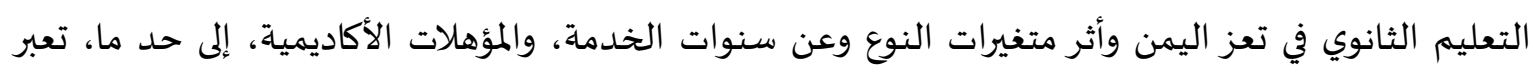

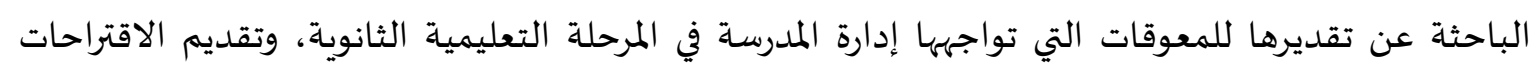

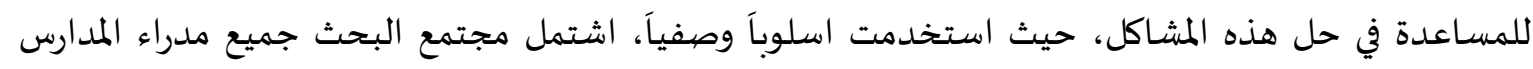

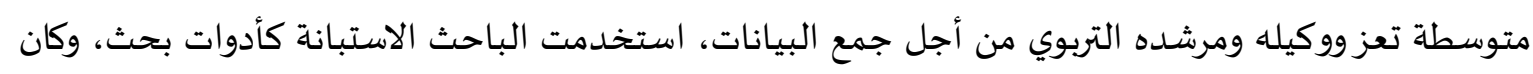

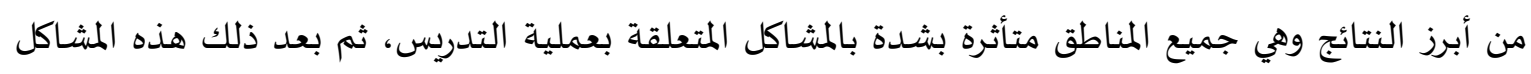

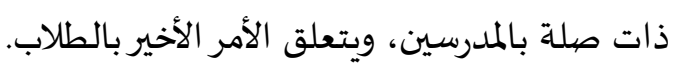
وأجرى أبو عودة (2004) دراسة هدفت إلى التعرف على المعوقات التي تواجه مديري وزارة التربية والتعليم في

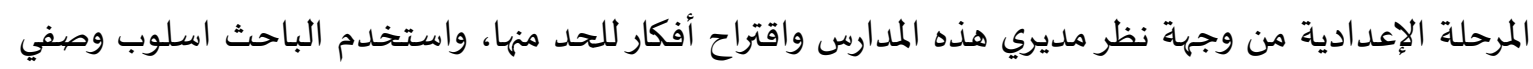




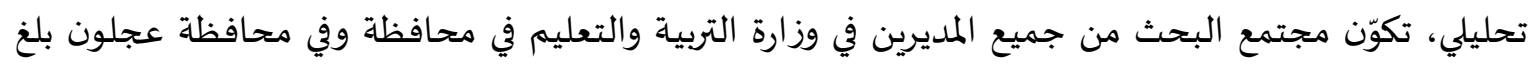

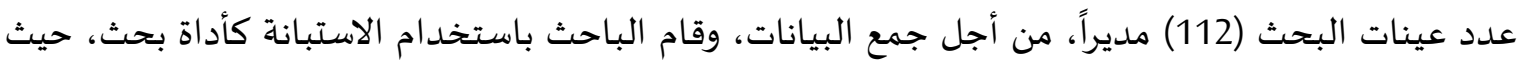

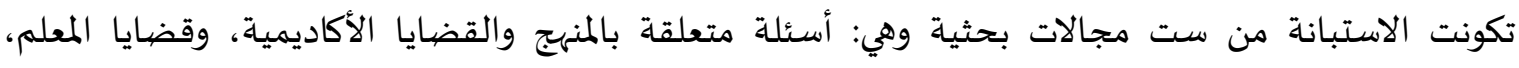
والقضايا المتعلقة بالطلاب، والقضايا المتعلقة بالمجتمع والقضايا المحلية، والقضايا المتعلقة ببناء المدارس

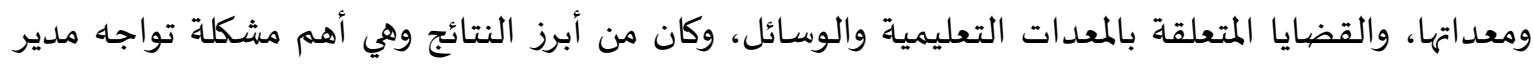

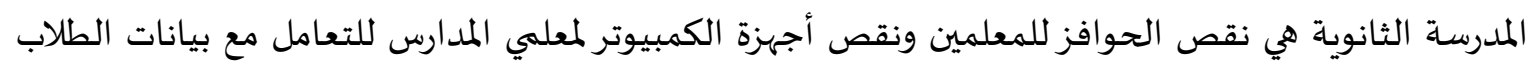
والتواصل معهم.

كما قام الهباش (2002) بدراسة هدفت إلى الكشف عن المعوقات الأكثر شيوعًا التي يواجهها مديري المدارس

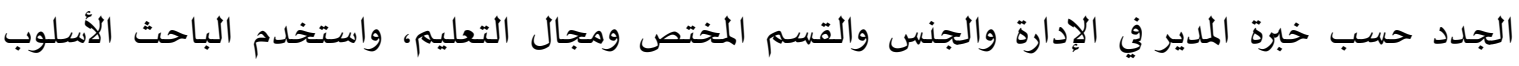

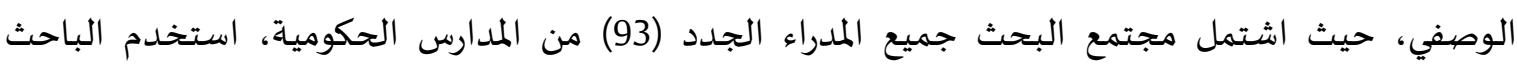

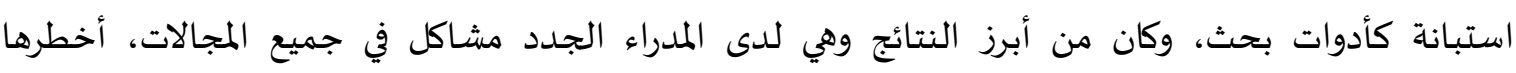
المعوقات البيئية في المدرسة. أجرى العاجز (2001) دراسة تهدف إلى تحديد واقع الإدارة المدرسية في مدارس البنات بمحافظة غزة وتحديد

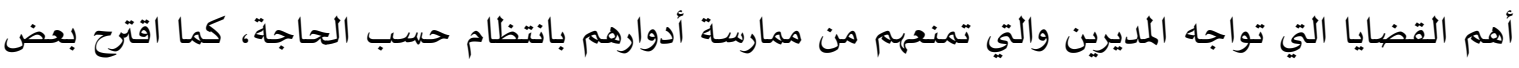

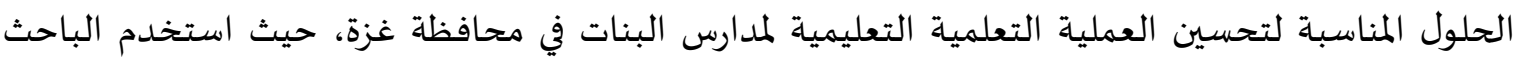
الأسلوب الوصفي والتحليلي، اشتمل مجتمع البحث من جميع المديرات البالغ عددهن بمحافظة غزة (201)

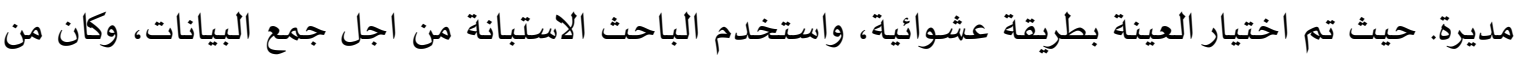

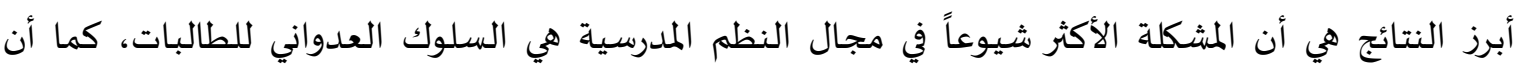

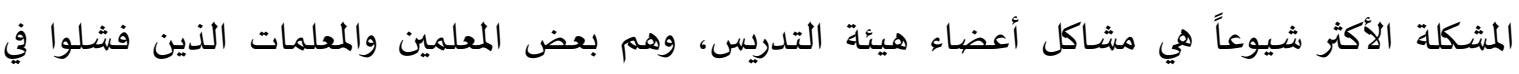

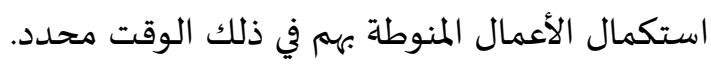

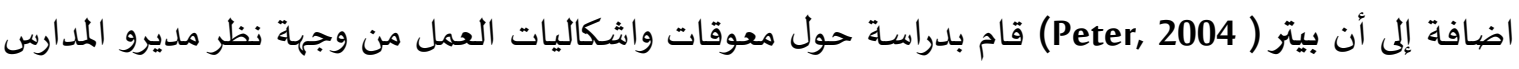

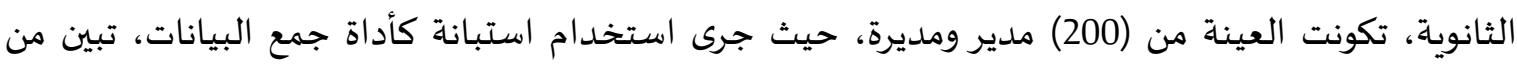

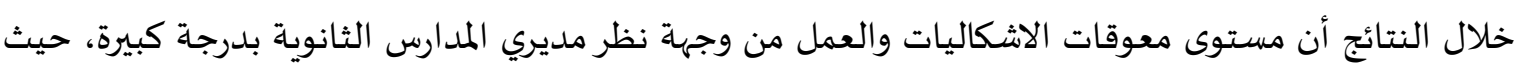

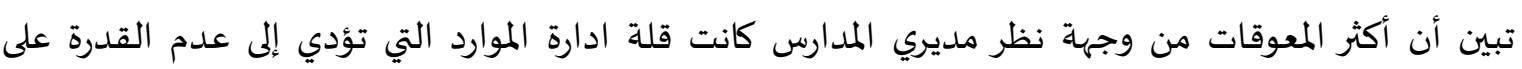
تحقيق النتائج المنشودة.

تعليق على الدّراسـات السـابقة: تناولت العديد من الدّراسات السابقة موضوعات ذات الدات صلة بالمعوقات الإدارية والفنية التي يواجهها مديرو المدارس وعلاقتها ببعض المتغيرات ونلاحظ ما يلي:

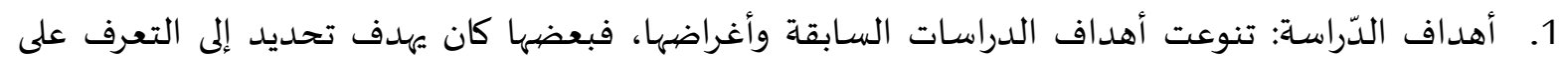

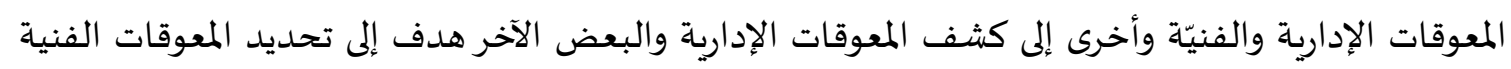

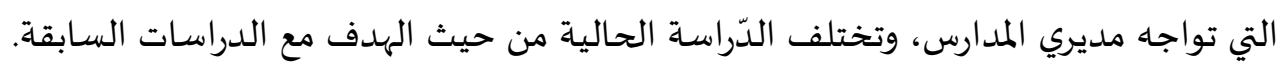

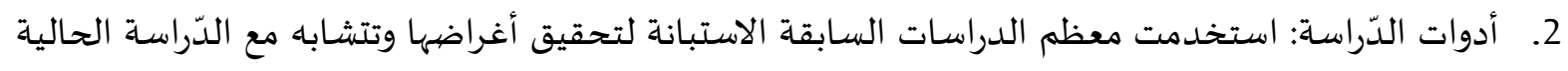
في استخدام الاستبانة لكن تختلف في عباراتها ومجالاتها. 
3. عينة الدّراسـة: شملت الدراسات السابقة عينات مختلفة تنوعت ما بين أعضاء هيئة التدريس في الجامعات،

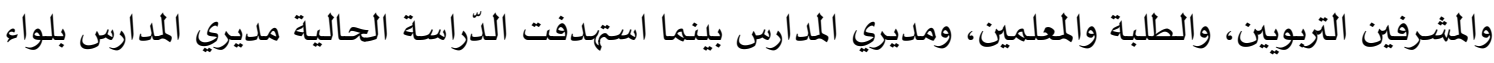
البادية الشمالية الغربية.

في ضوء عرض الدراسات السابقة نجدها تحدثت عن المعوقات الإدارية والفنية التي تواجه مديري المدارس

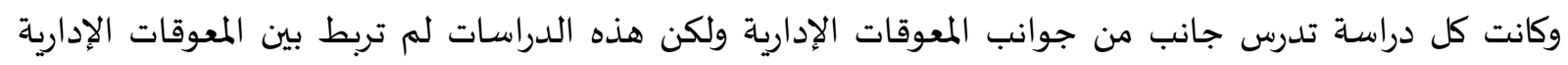

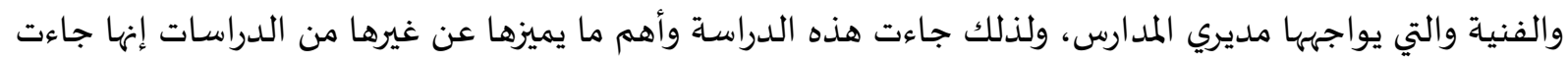

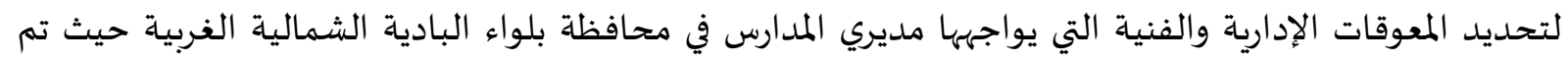

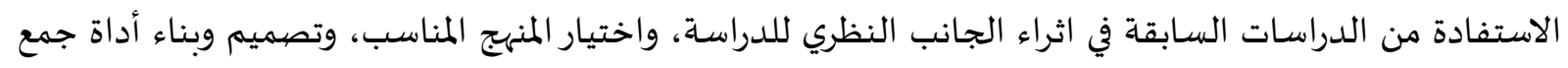

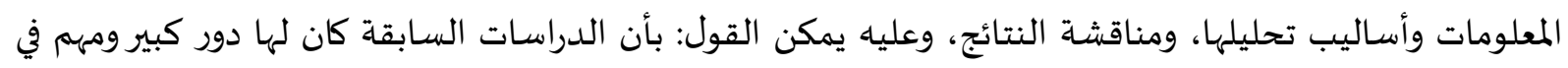

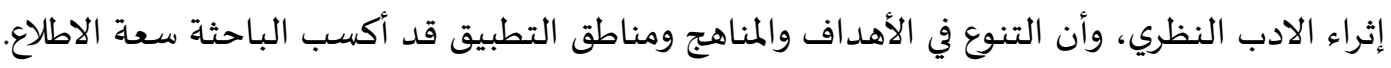

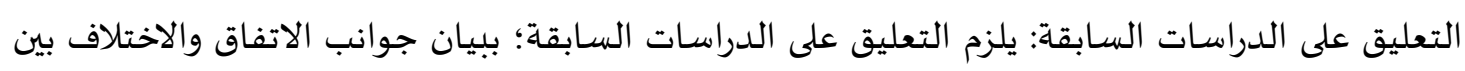

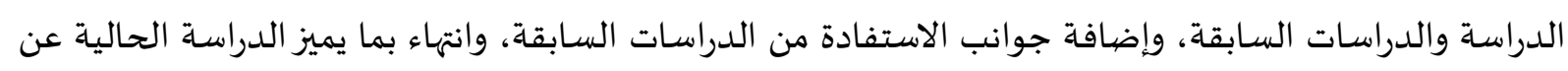
الدراسات السابقة.

3- منهجية الدّراسـة وإجراءاتها.

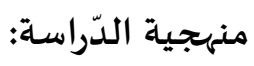
استعملت الباحثة في هذه الدراسة المنهج الوصفي والذي اعتمد على الأسلوب المستي باستخدام الاستبانة

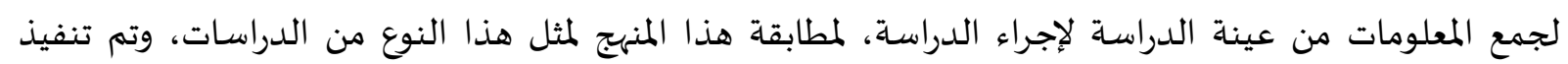
الأساليب الإحصائية الوصفية لتحليلها.

\section{مجتمع الدّراسـة وعيّنتها:}

تكونّ مجتمع الدّراسة من جميع مديري مدارس في مديرية تربية البادية الشمالية الغربية في العام الدراسي

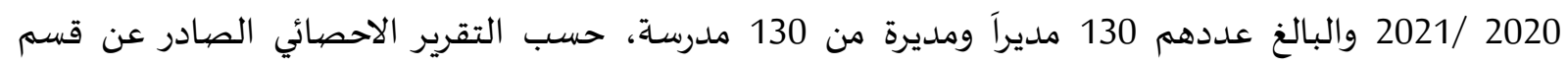

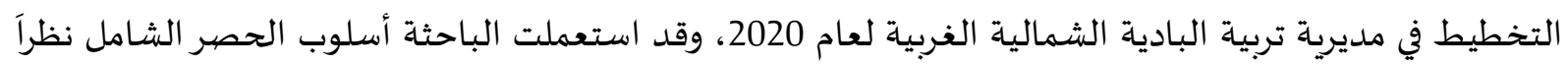

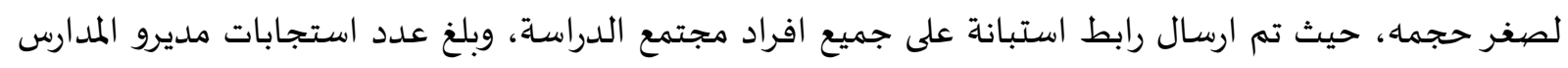

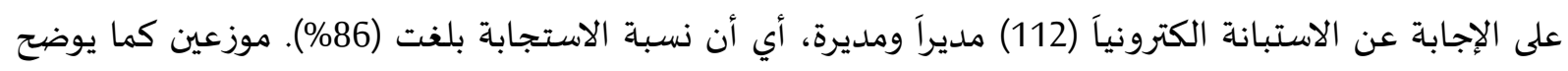

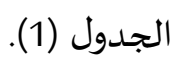

وصف العينة:

جدول رقم (1) التكرارات والنسب المئوية حسب متغيرات الدّراسـة يلزم تصيويب الفئات المتعلقة بعدد سنوات

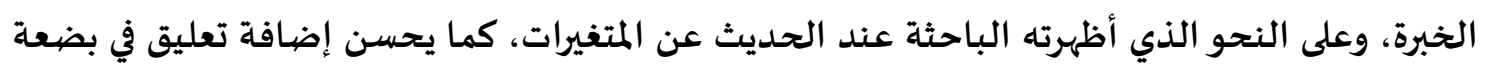
أسطر؛ حول دلالات الأعداد والنسب على النتائج ومصيداقئه التئها.

\begin{tabular}{|c|c|c|c|}
\hline النسبة & التكرار & الفئات & المتغير \\
\hline 43.8 & 49 & ذكر & \multirow{2}{*}{ الجنس } \\
\hline 56.3 & 63 & أنثى & \\
\hline
\end{tabular}




\begin{tabular}{|c|c|c|c|}
\hline النسبة & التكرار & الفئات & المتغير \\
\hline 53.6 & 60 & دبلوم عالي +بكالوريوس & \multirow{2}{*}{ المؤهل العلمي } \\
\hline 46.4 & 52 & دراسـات عليا & \\
\hline 24.1 & 27 & أقل من 15 سنة & \multirow{2}{*}{ عدد سـنوات الخبرة } \\
\hline 75.9 & 85 & 15 سنة فأكثر & \\
\hline 100.0 & 112 & المجموع & \\
\hline
\end{tabular}

أداة الدّراسة :استخدمت الباحثة الاستبانة أداة للدراسة، ولإعداد هذه الأداة تم الاستعانة بالأدب النظري

المتعلق بالموضوع، حيث تم بناء استبانة بالرجوع إلى عدد من الدراسات ابرزها دراسة الشمري والحربي (2019)

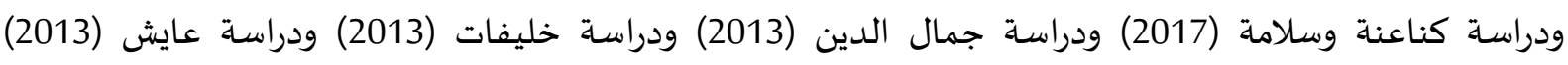

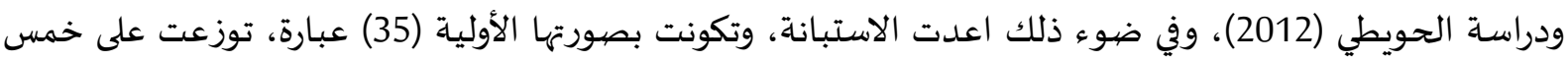

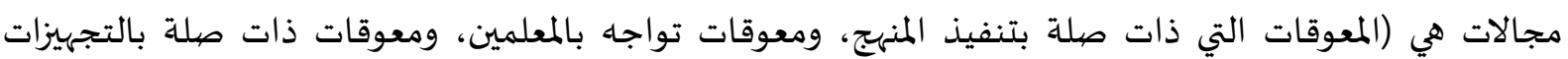

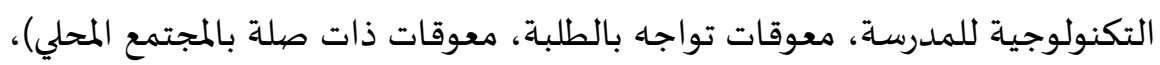

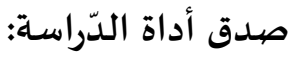
للتحقق من صداق أداة الدراسة قامت الباحثة بعرض الاستبانة على مجموعة من المحكمين من أعضاء

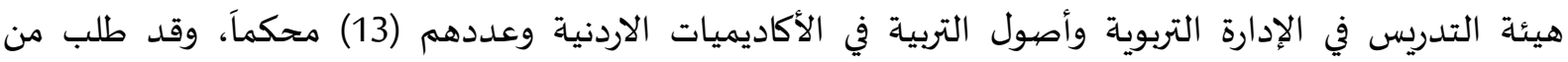
المحكمين تنقيح ومراجعة عبارات الاداة وذلك بهدف معرفة آرائهم، وملاحظاتهم ومقترحاتهم حول الاستبانة، ومدى الإدى

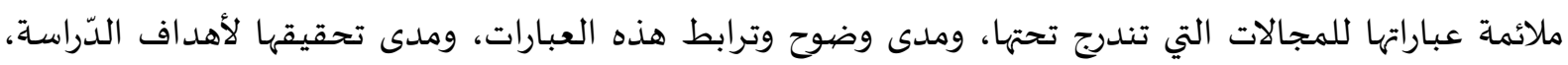

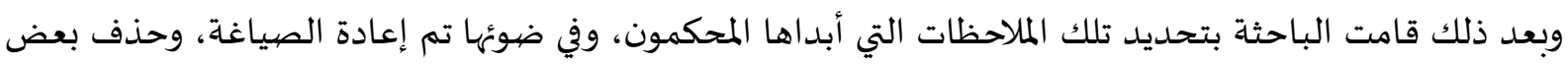

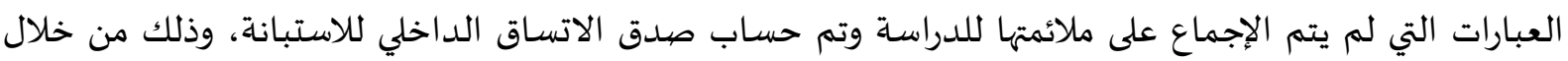
حساب معامل الارتباط بين كل عبارة من العبارات مع الدرجة الكلية للمجال الذي تنتمي لله.

ثبات أداة الدّراسة: للتأكد من ثبات أداة الدّراسة تم اختيار عينة استطلاعية بلغت (25) مديراً ومديرة، فقد تم اعتبار معالج

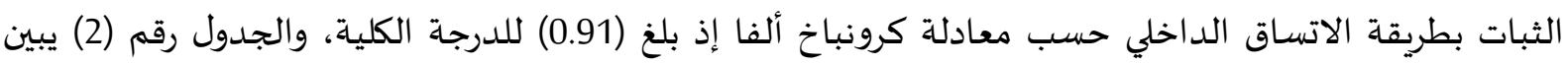

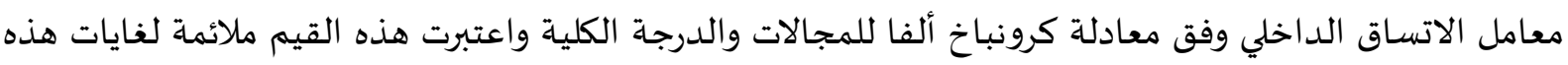

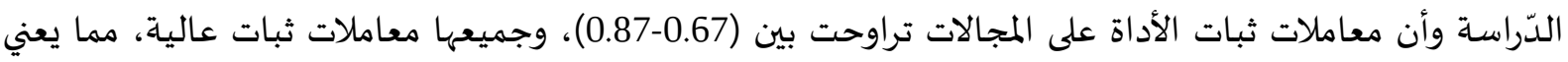
أن الأداة تتمتع بدرجات ثبات مقبولة تربويا وتفي بأغراض الدّراسة.

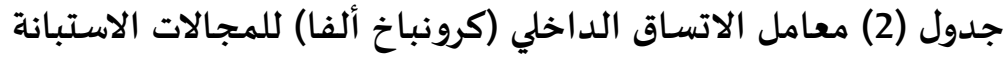

\begin{tabular}{|c|c|c|c|}
\hline 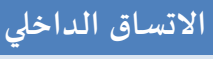 & 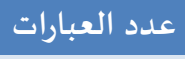 & 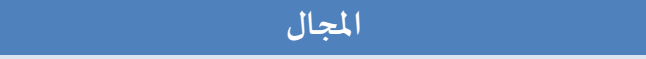 & 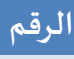 \\
\hline 0.67 & 6 & المعوقات التي ذات صلة بتنفيذ المنهاج & 1 \\
\hline 0.83 & 5 & معوقات ذات صلة بالمعلمين & 2 \\
\hline 0.78 & 7 & معوقات ذات صللة بالتجهيزات التكنولوجية للمدرسة & 3 \\
\hline 0.78 & 9 & معوقات ذات صلة بالطلبة & 4 \\
\hline 0.87 & 8 & معوقات ذات صلة بالمجتمع المحلي & 5 \\
\hline 0.91 & 35 & للأداة ككل & 6 \\
\hline
\end{tabular}


يبين الجدول (2) أن معاملات ثبات الأداة على المجالات تراوحت بين (0.67-0.87)، وجميعها معاملات ثبات

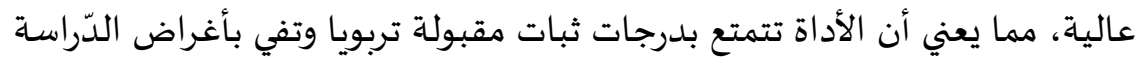

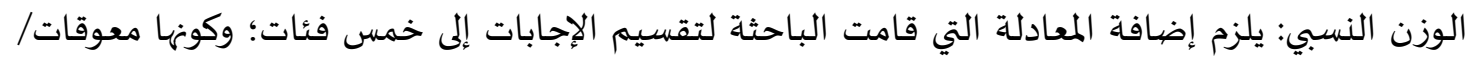

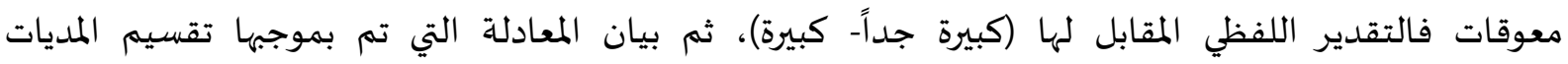
للمتوسطات، وتعديل القيم على النحو الذي قام باه المحكم وقبله ترقيم الجدول وتسميته. تم اعتماد سلم ليكرت

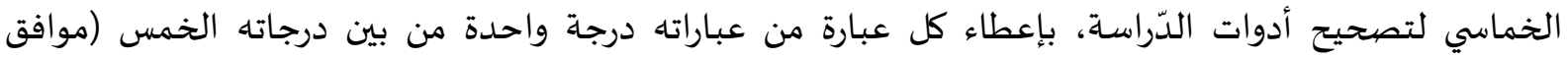

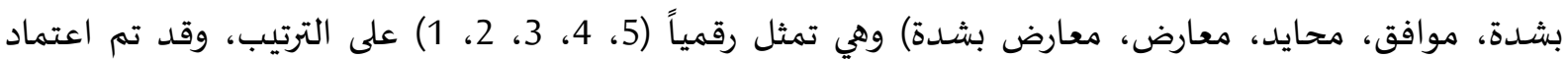
المقياس التالي لأغراض تحليل النتائج:

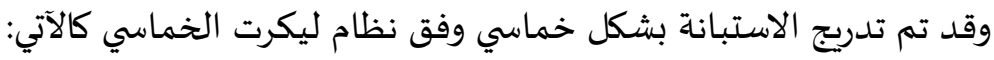
مرتفعة جداً

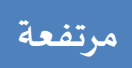
متوسطة نظم ليكرت

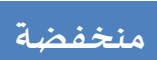

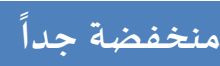

5

4

3

2

1

المعيار الإحصائي:

جدول (2) الأرقام عند الإدخال والمتوسطات ومدياتها والتقديرات اللفظية المقابلة لكل منها.

\begin{tabular}{|c|c|c|c|}
\hline التقديرات اللفظية & المتوسطات وملدياتها & الأرقام عند الإدخال & $\hat{\imath}$ \\
\hline صغيرة جداً & من 1- 1.80 & 1 & 1 \\
\hline صغيرة & من 1.81- 2.60 & 2 & 2 \\
\hline متوسطة & من2.61- 3.40 & 3 & 3 \\
\hline كبيرة & من3.41- 4.20 & 4 & 4 \\
\hline كبيرة جداً & من4.21- 5 & 5 & 5 \\
\hline
\end{tabular}

المعالجة الإحصيائية:

قامت الباحثة بإعداد استبانة؛ للكشف عن المعوقات الإدارية والفنيّة لدى مديري ومديرات المدارس

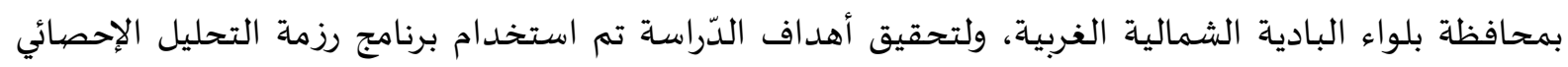

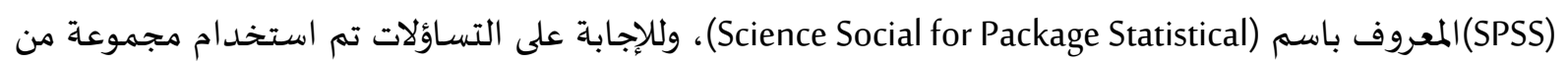

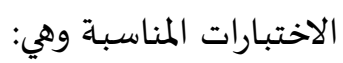

1- معامل ارتباط بيرسون للكشف عن العلاقة بين المتغيرات، والكشف عن الاتساق الداتخلي لمقياس الدّراسة. 2- - معادلة سبيرمان براون: لحساب الثبات بطريقه التجزئة النصفية. 3- معامل ألفا كرونباخ: لإيجاد ثبات أداة الدّراسة. 4- المتوسط الحسابي، والانحراف المعياري، والوزن النسبي. 5- تحليل التباين الأحادي (One Way Annova)للكشف عن دلالة الفروق بين متوسطات درجات أكثر من عينتين مستقلتين. 6- اختبار:T - Test للكشف عن دلالة الفروق بين متوسطات درجات عينين مستقلتين. 
4- عرض النتائج ومناقشتها. جدول (3) المتوسطات الحسابية والانحرافات المعيارية للمعوقات الفنيّة والإدارية التي يواجهها مديري المدارس ومسات

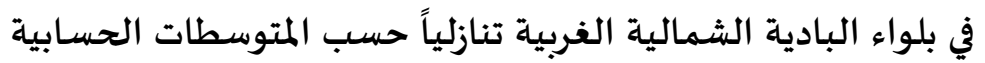

\begin{tabular}{|c|c|c|c|c|c|}
\hline التقدير & 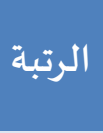 & الانحراف & المستوسط & 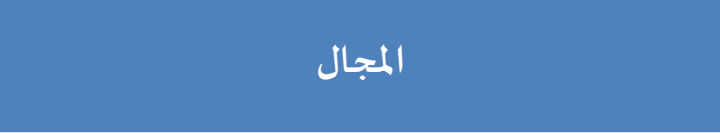 & 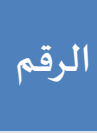 \\
\hline 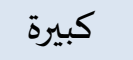 & 1 & .594 & 3.97 & معوقات ذات صلة بالمجتمع المحلي & 5 \\
\hline كبيرة & 2 & .657 & 3.76 & معوقات ذات صلة بالمعلمين & 2 \\
\hline 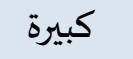 & 3 & .620 & 3.57 & المعوقات التي ذات صلة بتنفيذ المنهاج & 1 \\
\hline 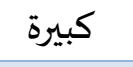 & 4 & .667 & 3.55 & معوقات ذات صلة بالتجهيزات التكنولوجية للمدرسة & 3 \\
\hline 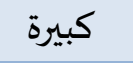 & 5 & .567 & 3.51 & معوقات ذات صلة بالطلبة & 4 \\
\hline 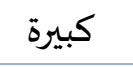 & & .465 & 3.67 & 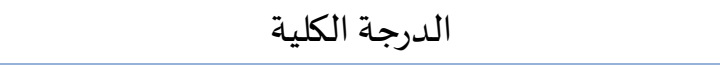 & \\
\hline
\end{tabular}

يبين الجدول (3) أن المتوسطات الحسابية قد تراوحت ما بين (3.51-3.97)، حيث جاءت المعوقات المتعلقة بالمجتمع المحلي في المرتبة الأولى بأعلى متوسط حسابي بلغ (3.97)، بينما جاءت المعوقات المتعلقة الماتلة بالطلبة في المرتبة الأخيرة وبمتوسط بلغ (3.51)، وبلغ المتوسط الحسابي للأداة ككل (3.67). وقد تم حساب المتوسطات الحسابية والانحرافات المعيارية لتقديرات أفراد عينة الدّراسة على عبارات المات كل مجال على حدة، حيث كانت على النحو التالي: ابل

المجال الأول: المعوقات التي ذات صلة بتنفيذ المنهاج جدول (4) المتوسطات الحسابية والانحرافات المعيارية للمعوقات المتعلقة بتنفيذ المنهاج مرتبة تنازلياً حسب المباج

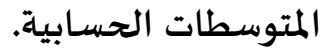

\begin{tabular}{|c|c|c|c|c|c|}
\hline التقدير & 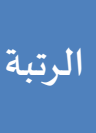 & الانتحراف & الحتوسط الحسابي & العبارات & $\hat{\imath}$ \\
\hline كبيرة جدا & 1 & .854 & 4.25 & $\begin{array}{c}\text { ضعف مشاركة المعلمين بإجراء البحوث التربوية المتعلقة بالمناهج } \\
\text { المقررة }\end{array}$ & 6 \\
\hline كبيرة & 2 & 1.006 & 3.79 & قلة توافروسائل التعليم المساعدة لتنفيذ المناهج & 3 \\
\hline 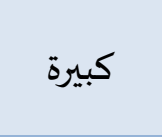 & 3 & 1.123 & 3.49 & قلة كفاية الدورات التدربية للمعلمين حول تحليل محتوى المناهج & 5 \\
\hline متوسطة & 4 & .982 & 3.34 & قلة مراعاة المناهج للفروق الفردية بين الطلبة & 2 \\
\hline متوسطة & 5 & .994 & 3.30 & تدني عدد الحصص اللامنهجية & 4 \\
\hline متوسطة & 6 & .969 & 3.25 & ندرة زيارة المشرف التربوي للمدارس والوقوف على تقديم المعلمين & 1 \\
\hline متوسطة & & .620 & 3.57 & المعوقات التي ذات صلة بتنفيذ المنهاج & \\
\hline
\end{tabular}

يبين الجدول (4) أن المتوسطات الحسابية قد تراوحت ما بين (3.25-4.25)، حيث جاءت العبارة رقم (6) لماتهات

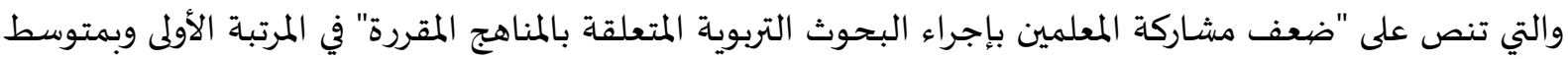
بلغ (4.25)، وجاءت العبارة رقم (3) والتي تنص على "قلة توافر وسائل التعليم المساعدة لتنفيذ المناهج" في المرتبة 
الثانية وبمتوسط بلغ (3.79)، وجاءت العبارة رقم (5) والتي تنص على "قلة كفاية الدورات التدريبية للمعلمين حول

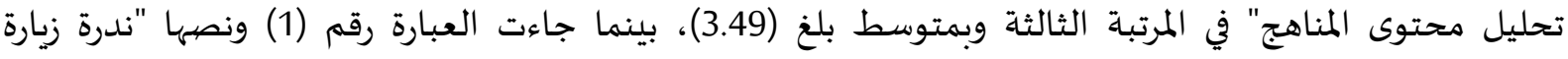
المشرف التربوي للمدارس والوقوف على تقديم المعلمين المناهج المقررة" بالمرتبة الأخيرة وبمتوسط بلغ المباءئ (3.25). وبلغ المتوسط الحسابي للمعوقات المتعلقة بتنفيذ المنهاج ككل (3.57)

المجال الثاني: معوقات ذات صلة بالمعلمين جدول (5) المتوسطات الحسابية والانحرافات المعيارية للمعوقات المتعلقة بالمعلمين مرتبة تنازلياً حسب بات المسان

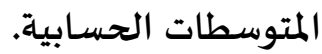

\begin{tabular}{|c|c|c|c|c|c|}
\hline التقدير & الرتبة & 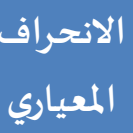 & الحسوسط الحسب & 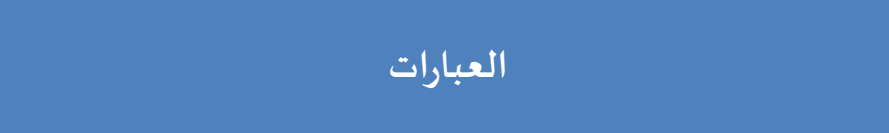 & $\hat{\imath}$ \\
\hline كبيرة & 1 & .961 & 3.94 & انخفاض الروح المعنوية لدى المعلمين & 11 \\
\hline كبيرة & 2 & .851 & 3.85 & عدم وجود خطة واضحة لتبادل الخبرات بين المعلمين القدامى والجدد & 7 \\
\hline كبيرة & 3 & .935 & 3.84 & ضعف بعض المعلمين في توظيف استراتيجيات التدريس التربوية & 9 \\
\hline 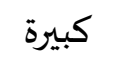 & 4 & .875 & 3.60 & ضعف قدرة بعض المعلمين على ضبط النظام الصفي & 10 \\
\hline كبيرة & 5 & .964 & 3.59 & قلة استخدام المعلمين للوسائل والأسـاليب والأنشطة في التحضير الجيد لتوضيح محتوى المناهج المقررة & 8 \\
\hline 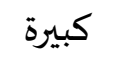 & & .657 & 3.76 & معوقات ذات صلة بالمعلمين & \\
\hline
\end{tabular}

يبين الجدول (5) أن المتوسطات الحسابية قد تراوحت ما بين (3.59-3.94)، حيث جاءت العبارة رقم (11)

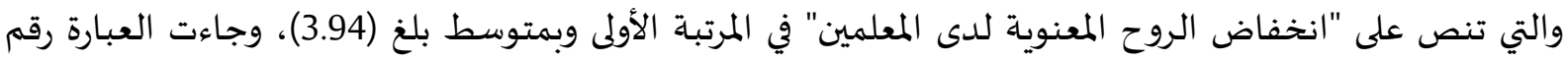
(7) والتي تنص على "عدم وجود خطة واضحة لتبادل الخبرات بين المعلمين القدامى والجدد" في المرتبة الثانية وبمتوسط بلغ (3.85)، وجاءت العبارة رقم (9) والتي تنص على "ضعف وجن بعض وضلى المعلمين في توظيف استراتيجيات

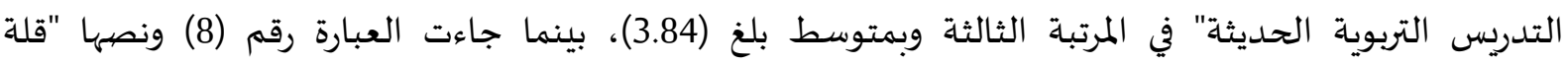

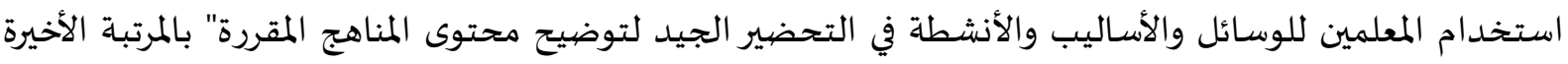
وبمتوسط بلغ (3.59). وبلغ المتوسط الحسابي للمعوقات المتعلقة بالمعلمين ككل (3.76).

المجال الثالث: معوقات ذات صلة بالتجهيزات التكنولوجية للمدرسة

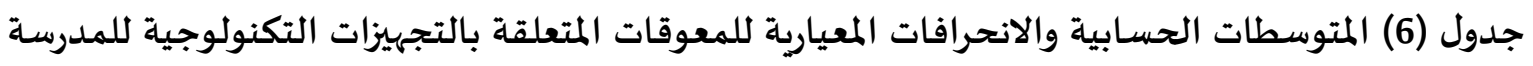
مرتبة تنازلياً حسب المتوسطات الحسابية

\begin{tabular}{|c|c|c|c|c|c|}
\hline 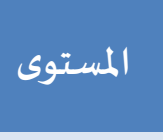 & الرتبة & الالنحراف & المتوسط الحسابي & العبارات & $\hat{\imath}$ \\
\hline كبيرة جدا & 1 & .874 & 4.39 & أجهزه الحاسوب في المدرسة لا تتناسب و أعداد الطلبة & 14 \\
\hline 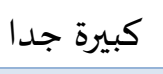 & 2 & .903 & 4.24 & ضعف شبكات الانترنت & 18 \\
\hline كبيرة جدا & 3 & 1.013 & 4.23 & عدم توفر أجهزة حاسوب لدى المعلمين في المدرسة لمعالجة & 15 \\
\hline
\end{tabular}




\begin{tabular}{|c|c|c|c|c|c|}
\hline المستوى & الرتبة & الانحراف - المعياري & المتوسط الحسابي & 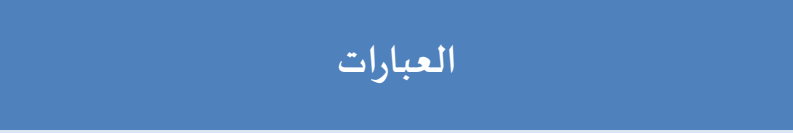 & $\hat{\imath}$ \\
\hline & & & & 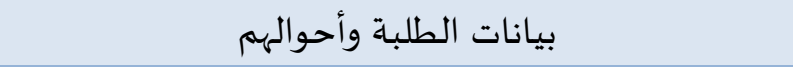 & \\
\hline متوسطة & 4 & 1.007 & 3.38 & ضعف توظيف التكنولوجيا المتوفرة في العمل التربوي & 13 \\
\hline متوسطة & 5 & 1.068 & 3.06 & افتقار الإدارة المدرسية لاستخدام الوسائل التكنولوجية & 16 \\
\hline متوسطة & 6 & 1.067 & 2.82 & ضعف المهارات التكنولوجية لدى مديري المدارس & 17 \\
\hline 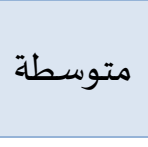 & 7 & 1.170 & 2.73 & اقتصار مفهوم التكنولوجيا الإدارية لدى المدير على توفير & 12 \\
\hline 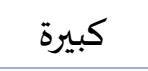 & & .667 & 3.55 & معوقات ذات صلة بالتجهيزات التكنولوجية للمدرسة & \\
\hline
\end{tabular}

يبين الجدول (6) أن المتوسطات الحسابية قد تراوحت ما بين (2.73-4.39)، حيث جاءت العبارة رقم (14)

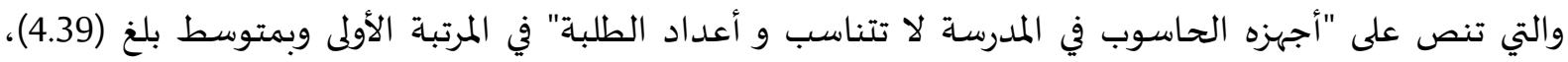

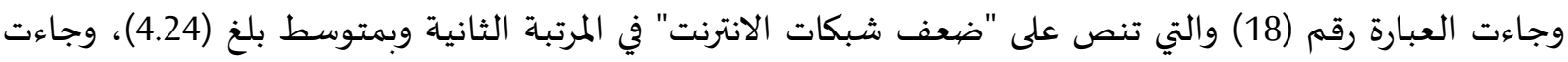

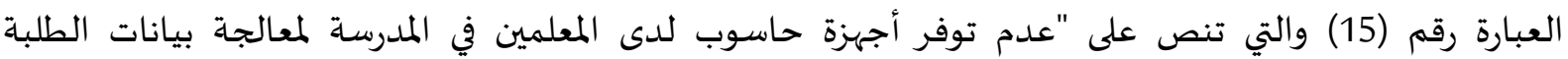

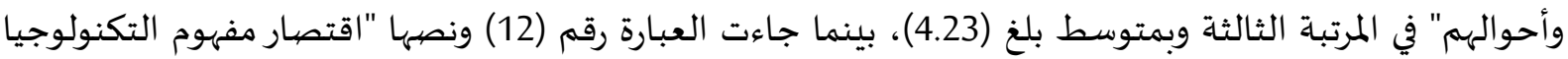

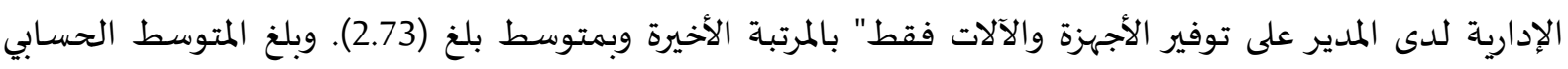

للمعوقات المتعلقة بالتجهيزات التكنولوجية للمدرسة ككل (3.55).

المجال الرابع: معوقات ذات صلة بالطلبة

جدول (7) المتوسطات الحسابية والانحرافات المعيارية للمعوقات المتعلقة بالطلبة مرتبة تنازلياً حسب دات دات المتوسطات الحسابية

\begin{tabular}{|c|c|c|c|c|c|}
\hline التقدير & 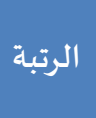 & 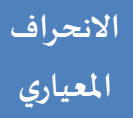 & المتوسط المسبي & 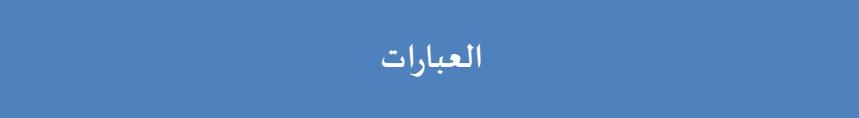 & $\hat{\imath}$ \\
\hline 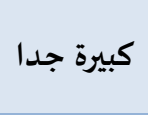 & 1 & .812 & 4.41 & انخفاض مستوى التحصيل لدى الطلبة نتيجة الاستمرار بالتعلم عن & 22 \\
\hline 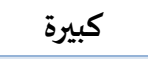 & 2 & .681 & 4.07 & عدم التزام بعض الطلبة بتنفيذ الواجبات البيتية & 20 \\
\hline 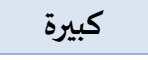 & 3 & .880 & 3.73 & ضعف استجابة الطلبة للخطط العلاجية لعملية التعلم & 26 \\
\hline 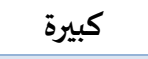 & 4 & 1.074 & 3.69 & الاكتظاظ المتزايد في عدد الطلبة في الصف الواحد & 25 \\
\hline متوسطة & 5 & .968 & 3.37 & كثرة غياب الطلبة دون مبرر & 24 \\
\hline 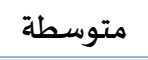 & 6 & .832 & 3.33 & تدني مستوى النظافة لدى بعض الطلاب & 21 \\
\hline متوسطة & 7 & 1.018 & 3.16 & تسرب بعض الطلبة من المدرسة & 23 \\
\hline 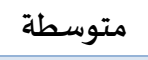 & 8 & .975 & 3.07 & إساءة بعض الطلبة للمعلمين & 19 \\
\hline متوسطة & 9 & 1.016 & 2.76 & إساءة بعض المعلمين اللفظية أو الجسدية أو النفسية لبعض الطلبة & 27 \\
\hline 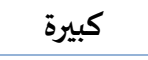 & & .567 & 3.51 & 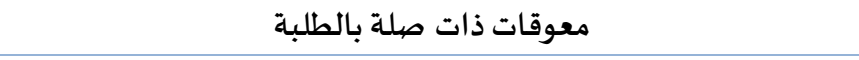 & \\
\hline
\end{tabular}


يبين الجدول (7) أن المتوسطات الحسابية قد تراوحت ما بين (2.76-4.41)، حيث جاءت العبارة رقم (22) والتي تنص على "انخفاض مستوى التحصيل لدى الطلبة نتيجة الاستمرار بالتعلم عن بعد" في المرتبة الأولى

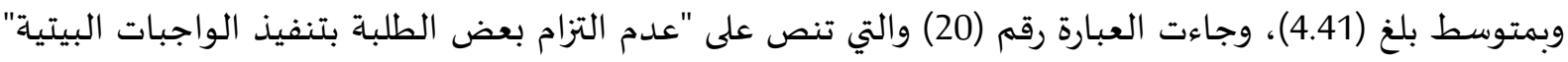

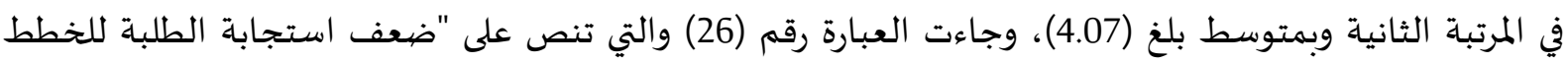

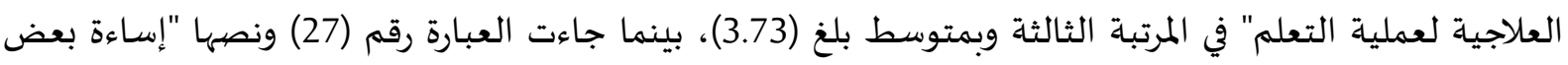

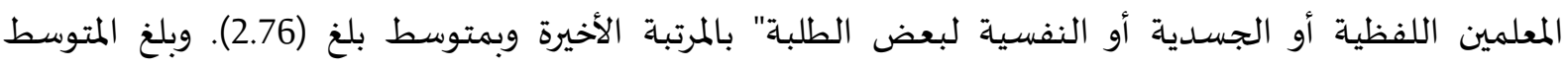
الحسابي للمعوقات المتعلقة بالطلبة ككل (3.51).

المجال الخامس: معوقات ذات صللة بالمجتمع المحلي

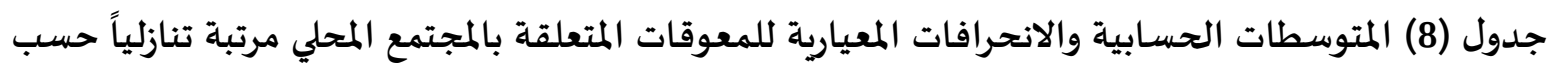
المتوسطات الحسابية

\begin{tabular}{|c|c|c|c|c|c|}
\hline التقدير & 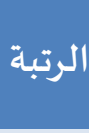 & 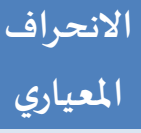 & المستوسط & 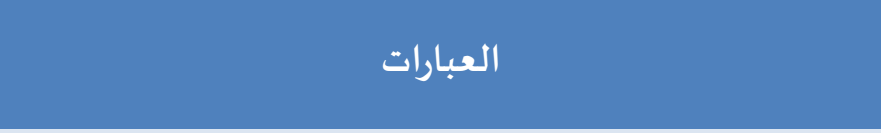 & $\hat{r}$ \\
\hline كبيرة جدا & 1 & .688 & 4.38 & ضعف قدرة بعض أولياء الأمور على استخدام التكنولوجيا & 35 \\
\hline كبيرة جدا & 2 & .832 & 4.21 & ضعف مشاركة المجتمع المحلي في تقديم الدعم المادي والمعنوي & 33 \\
\hline 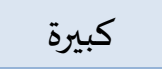 & 3 & .862 & 4.15 & ضيعف متابعة أولياء الأمور لأبنائهم & 31 \\
\hline 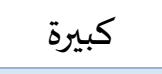 & 4 & .775 & 4.11 & ضعف تفاعل بعض أولياء الأمور مع أنشطة المدرسة & 29 \\
\hline كبيرة & 5 & .904 & 4.04 & عدم اكتراث بعض أولياء الأمور حول سوء سلوك أبنائهم الطلبة & 34 \\
\hline 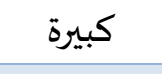 & 6 & .811 & 4.03 & ضعف مشـاركة أولياء الأمور بمجالس الإباء والمعلمين & 32 \\
\hline 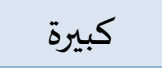 & 7 & .807 & 3.88 & قلة تفاعل مؤسسات المجتمع المحلي مع أنشطة المدرسة & 28 \\
\hline 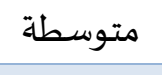 & 8 & 1.083 & 2.92 & تدخل بعض أولياء الأمور في شؤون المدرسة & 30 \\
\hline كبيرة & & .594 & 3.97 & معوقات ذات صلة بالمجتمع المحلي & \\
\hline
\end{tabular}

يبين الجدول (8) أن المتوسطات الحسابية قد تراوحت ما بين (2.92-4.38)، حيث جاءت المات العبارة رقم (35)

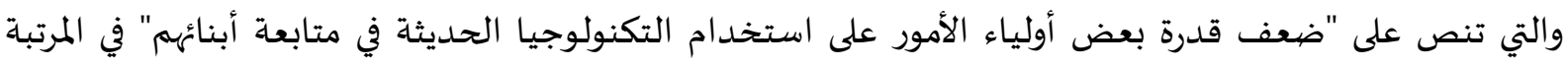

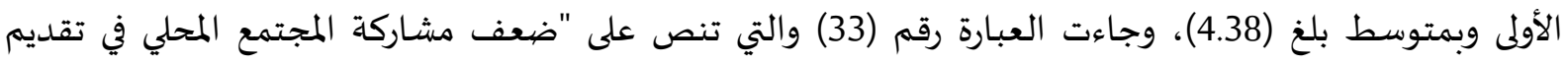

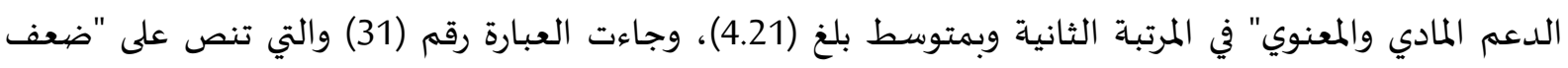

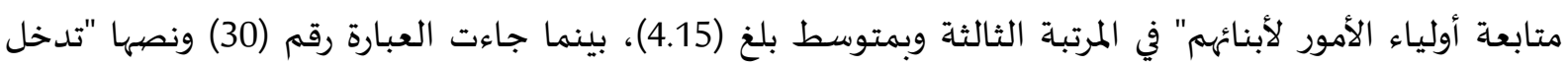

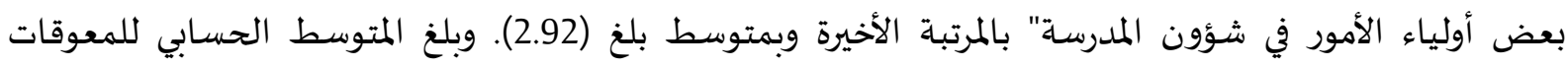
المتعلقة بالمجتمع المحلي ككل (3.97). 
نتائج السؤال الثاني: هل توجد فروق ذات دلالة إحصبائية عند مسـتوى الدلالة (م=0.05 ) في المعوقات الإدارية

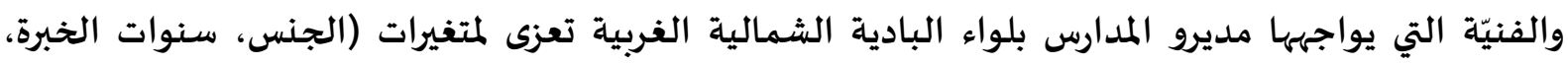

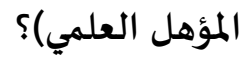

وللإجابة عن هذا السؤال تم استخراج المتوسطات الحسابية والانحرافات المعيارية للمعوقات الإدارية

والفنيّة التي يواجهها مديري المدارس في بلواء البادية الشمالية الغربية حسب متغيرات الجنس، سنوات الخبرة، المؤهل العلمي، ولبيان الفروق الإحصائية بين المتوسطات الحسابية تم استخدام اختبار "ت"، والجداول رقم (9)

يوضح ذلك.

جدول (9) المتوسطات الحسابية والانحرافات المعيارية للمعوقات الإدارية والفنية التي يواجهها مديرو المدارس

بلواء البادية الشمالية الغربية حسب متغيرات الجنس، سنوات الخبرة، المؤهل العلمي.

\begin{tabular}{|c|c|c|c|c|c|c|c|c|}
\hline الكلية & بالمجتملق & بالطلقة & 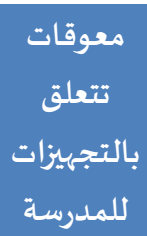 & بتعلق & تتعلق بتنفيذ معوقات & المتوسط & الفئات & المتفير \\
\hline 3.73 & 4.04 & 3.57 & 3.51 & 3.90 & 3.65 & المتوسط & ذكر & \multirow{2}{*}{ الجنس } \\
\hline 3.62 & 3.91 & 3.47 & 3.58 & 3.65 & 3.51 & المتوسط & أنثى & \\
\hline 3.69 & 3.97 & 3.56 & 3.60 & 3.79 & 3.50 & المتوسط & بكالوريوس عالي+ & \multirow{2}{*}{ العلمي } \\
\hline 3.65 & 3.96 & 3.45 & 3.49 & 3.73 & 3.65 & المتوسط & دراسـات عليا & \\
\hline 3.75 & 4.00 & 3.55 & 3.59 & 3.91 & 3.76 & المتوسط & اقل من 15 سنة & \multirow{2}{*}{ سنوات الخبرة } \\
\hline 3.64 & 3.96 & 3.50 & 3.54 & 3.72 & 3.51 & المتوسط & 15سنة فأكثر & \\
\hline
\end{tabular}

يبين الجدول (9) تبايناً ظاهرياً في المتوسطات الحسابية والانحرافات المعيارية للمعوقات الإدارية والفنية التي يواجهها مديري المدارس في بلواء البادية الشمالية الغربية بسبب اختلاف فئات متغيرات الجنس، سنوات الخبرة، المؤهل العلمي.

ولبيان دلالة الفروق الإحصائية بين المتوسطات الحسابية تم استخدام تحليل التباين الثلاثي المتعدد

جدول (10).

جدول (10) تحليل التباين الثلاثي المتعدد لأثر الجنس وسنوات الخبرة على مجالات المعوقات الإدارية والفنية

\begin{tabular}{|c|c|c|c|c|c|c|}
\hline الإحصائية & قيمة & متوسط المربعات & درجات & مجمبوع المربعات & 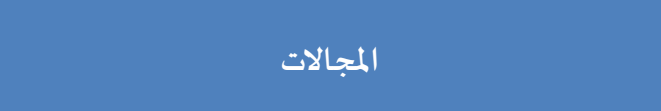 & مصيدر التباين \\
\hline .270 & 1.227 & .459 & 1 & .459 & المعوقات التي ذات صلة بتنفيذ المنهاج & \multirow{6}{*}{ هوتلنج=الجنس } \\
\hline .030 & 4.853 & 2.020 & 1 & 2.020 & معوقات ذات صلة بالمعلمين & \\
\hline .693 & .157 & .071 & 1 & .071 & معوقات ذات صلة بالتجهيزات التكنولوجية للمدرسة & \\
\hline .256 & 1.302 & .420 & 1 & .420 & معوقات ذات صلة بالطلبة & \\
\hline .226 & 1.483 & .531 & 1 & .531 & معوقات ذات صلة بالمجتمع المحلي & \\
\hline .202 & 1.648 & .356 & 1 & .356 & الدرجة الكلية & \\
\hline .334 & .940 & .352 & 1 & .352 & المعوقات التي ذات صلة بتنفيذ المنهاج & \multirow{4}{*}{ هوتلنج=المؤهل العلمي. } \\
\hline .306 & 1.056 & .440 & 1 & .440 & معوقات ذات صلة بالمعلمين & \\
\hline .417 & .663 & .300 & 1 & .300 & معوقات ذات صللة بالتجهيزات التكنولوجية للمدرسة & \\
\hline .204 & 1.634 & .528 & 1 & .528 & معوقات ذات صلة بالطلبة & \\
\hline
\end{tabular}




\begin{tabular}{|c|c|c|c|c|c|c|}
\hline الإحصائية & فيمة ف & متوسط المربعات & درجات & المربعات & 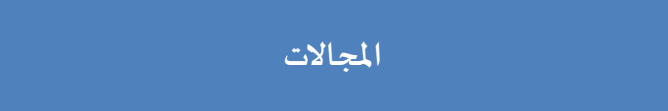 & مصدر التباين \\
\hline .775 & .082 & .029 & 1 & .029 & معوقات ذات صلة بالمجتمع المحلي & \multirow{8}{*}{ 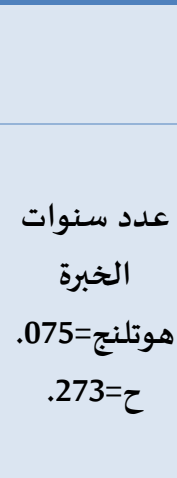 } \\
\hline .476 & .511 & .110 & 1 & .110 & الدرجة الكلية & \\
\hline .074 & 3.253 & 1.217 & 1 & 1.217 & المعوقات التي ذات صلة بتنفيذ المنهاج & \\
\hline .125 & 2.396 & .997 & 1 & .997 & معوقات ذات صلة بالمعلمين & \\
\hline .671 & .182 & .082 & 1 & .082 & معوقات ذات صلة بالتجهيزات التكنولوجية للمدرسة & \\
\hline .546 & .367 & .118 & 1 & .118 & معوقات ذات صلة بالطلبة & \\
\hline .713 & .136 & .049 & 1 & .049 & معوقات ذات صهلة بالمجتمع المحلي & \\
\hline \multirow[t]{13}{*}{.253} & 1.322 & .285 & 1 & .285 & الدرجة الكلية & \\
\hline & & .374 & 108 & 40.424 & المعوقات التي ذات صلة بتنفيذ المنهاج & \multirow{6}{*}{ 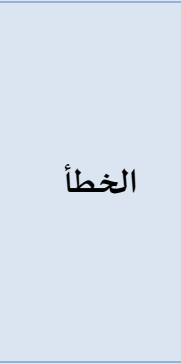 } \\
\hline & & .416 & 108 & 44.959 & معوقات ذات صلة بالمعلمين & \\
\hline & & .453 & 108 & 48.881 & معوقات ذات صلة بالتجهيزات التكنولوجية للمدرسة & \\
\hline & & .323 & 108 & 34.861 & معوقات ذات صلة بالطلبة & \\
\hline & & .358 & 108 & 38.659 & معوقات ذات صلة بالمجتمع المحلي & \\
\hline & & .216 & 108 & 23.318 & الدرجة الكلية & \\
\hline & & & 111 & 42.707 & المعوقات التي ذات صلة بتنفيذ المنهاج & \multirow{6}{*}{ 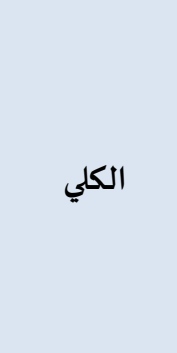 } \\
\hline & & & 111 & 47.963 & معوقات ذات صلة بالمعلمين & \\
\hline & & & 111 & 49.367 & معوقات ذات صلة بالتجهيزات التكنولوجية للمدرسة & \\
\hline & & & 111 & 35.742 & معوقات ذات صلة بالطلبة & \\
\hline & & & 111 & 39.225 & معوقات ذات صلة بالمجتمع المحلي & \\
\hline & & & 111 & 23.964 & الدرجة الكلية & \\
\hline
\end{tabular}

يتبين من الجدول (10) الآتي:

- عدم وجود فروق ذات دلالة إحصائية (א) لأثر الجنس في جميع المجالات وفي الدرجة الكلية باستثناء المعوقات المتعلقة بالمعلمين وجاءت الفروق لصالح الذكور.

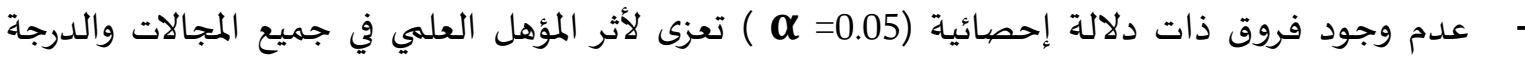

- عدم وجود فروق ذات دلالة إحصائية (

نتائج السؤال الثالث والذي ينص على: ما مقترحاتكم لمعالجة المعوقات الإدارية والفنيّة التي يواجهها مديرو المدارس في بلواء البادية الشمالية الغربية؟ للإجابة عن هذا السؤال تم تفريغ إجابات السؤال الثوال الثالث كماتها

يلي:

1- - ت تعين مساعدين للأمور الفنية والإدارية.

2- - 2- - التنمية المهنية

3- توفير الحواسيب الكافية للمدرسة والمتابعة الاشرافية للمعلمين

4- توفر بنية تحتية صحيحة، وتوفر مختبرات تحاكي وتواكب الانفجار المعرفي. 
مناقشـة النتائج:

مناقشة نتائج السؤال الأول الذي ينص على: ما المعوقات الإدارية والفنيّة التي يواجهها مديرو المدارس في

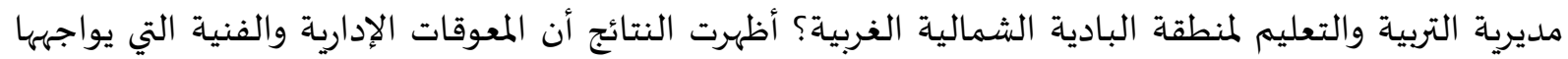

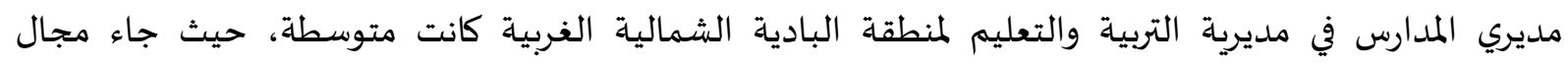

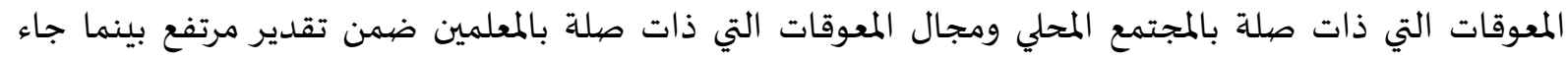

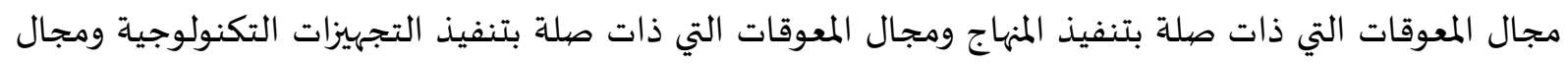

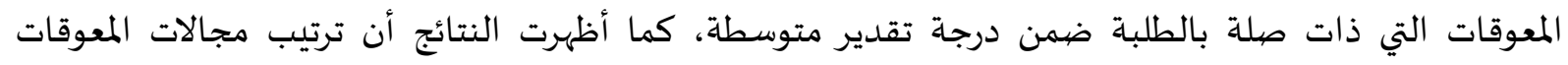
الإدارية والفنية التي يواجهها مديري المدارس في مديرية التربية والتعليم لمنطقة البادية الشمالية الغربية تبعاً

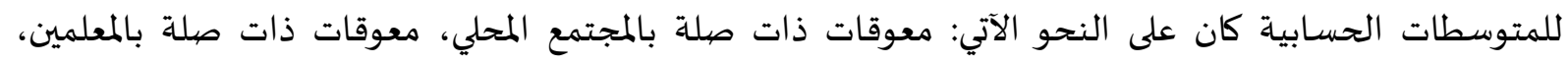

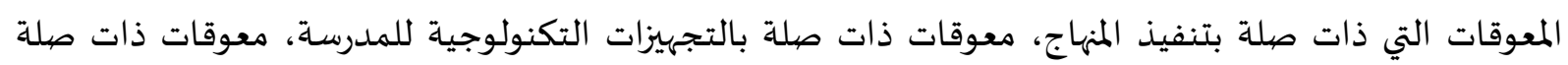

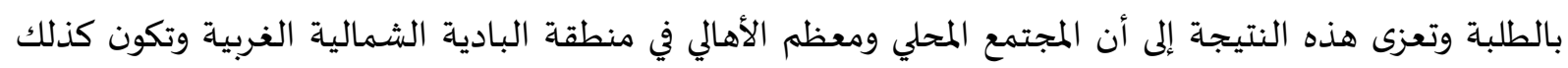

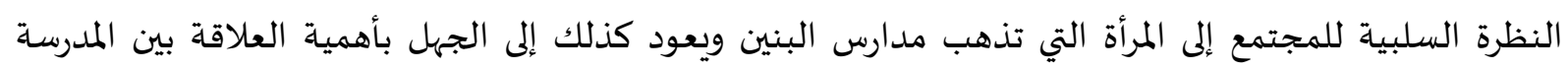

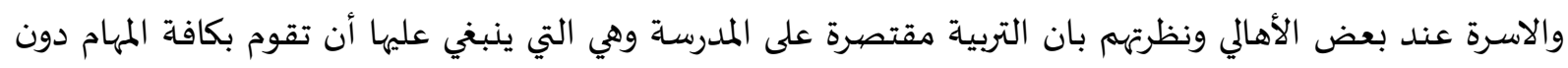

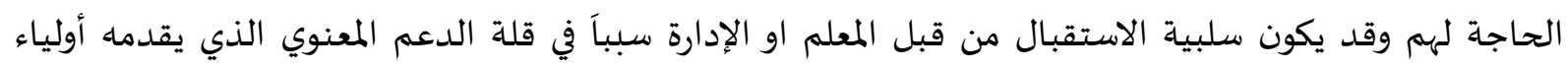

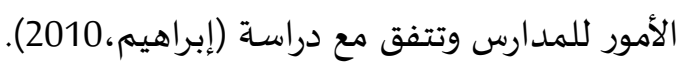
أما مناقشة النتائج التي ذات دراسة (إيراهيم صلة بكل مجال من مجالات الدّراسة كما يلي:

أولاً: مجال المعوقات ذات صلة بالمجتمع المحلي

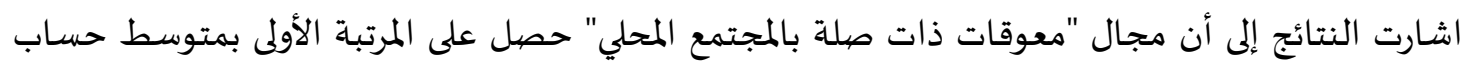

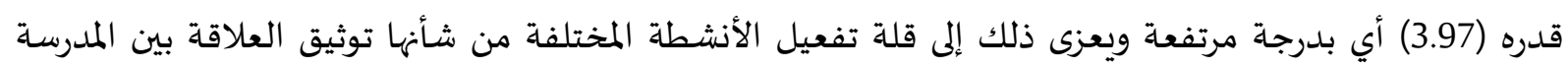

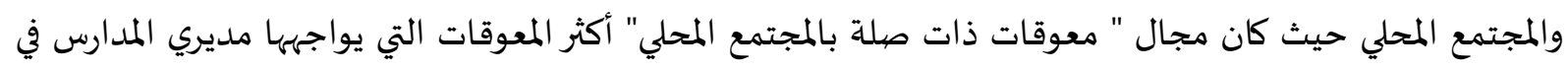

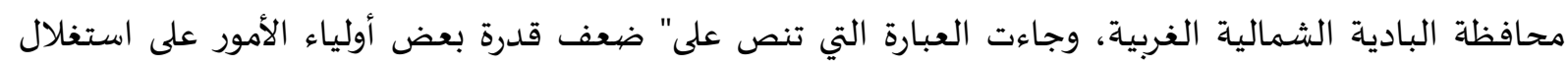

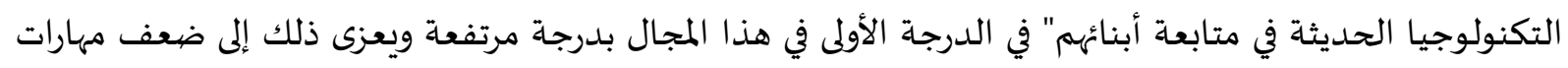

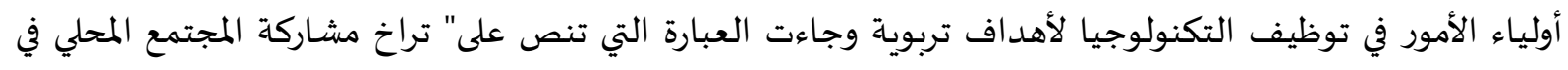

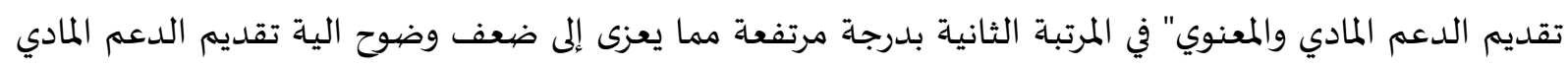
والمعنوي من وإلى المدرسة.

ثانياً: مجال المعوقات ذات صلة بالمعلمين أشارت النتائج إلى أن مجال" معوقات ذات هات صلة باتلة بالمعلمين حصل على المرتبة الثانية بمتوسط حساب

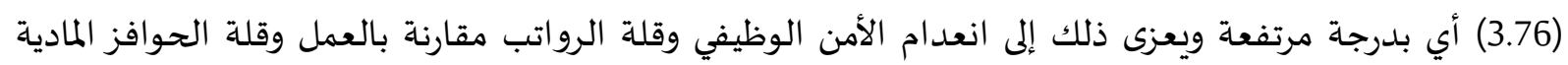

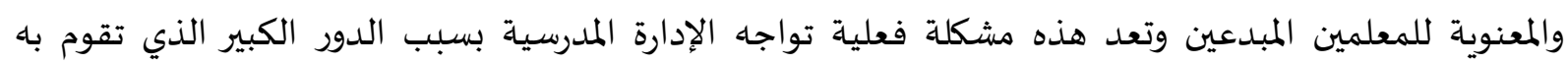

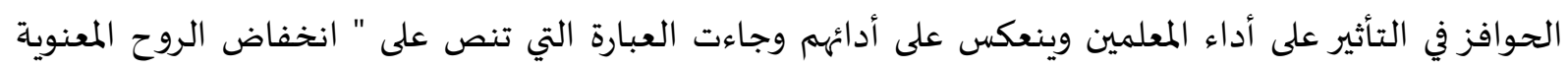

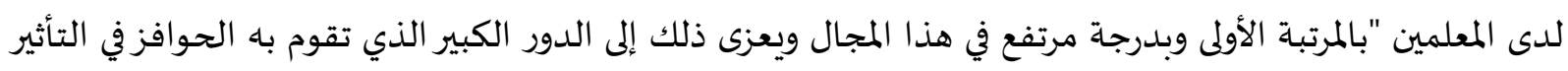

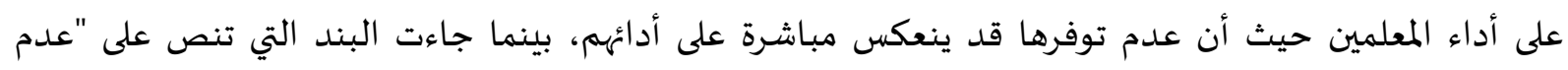

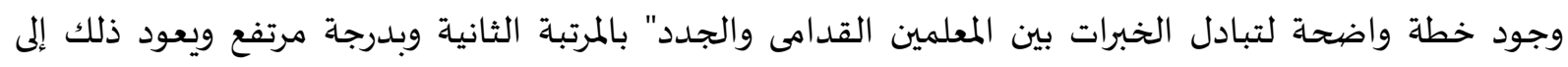

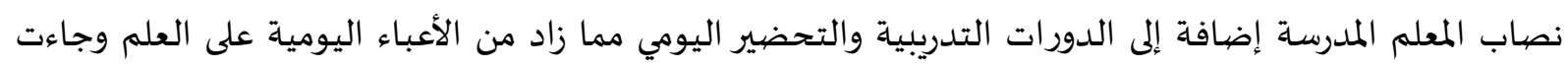


العبارة التي تنص على "ضعف قدرة بعض المعلمين على ضبط النظام الصفي" بالمرتبة قبل الأخيرة وبدرجة متوسط

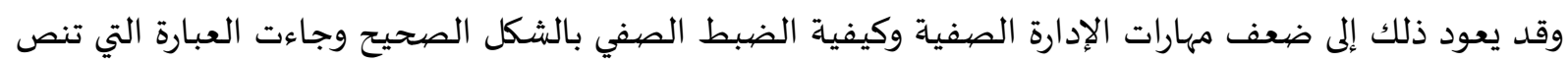

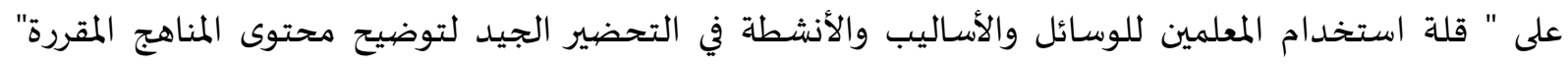

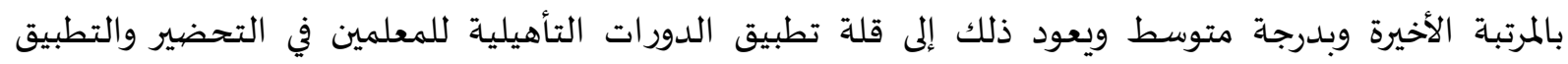

ثالثا: مجال المعوقات التي ذات صلة بالمنهاج

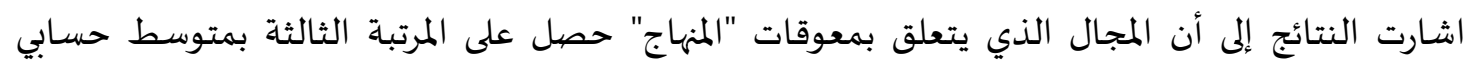

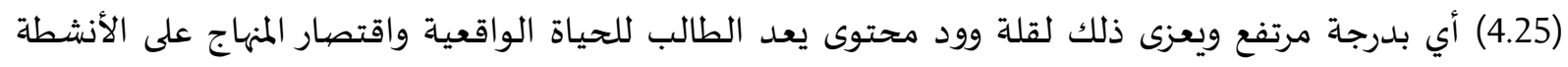

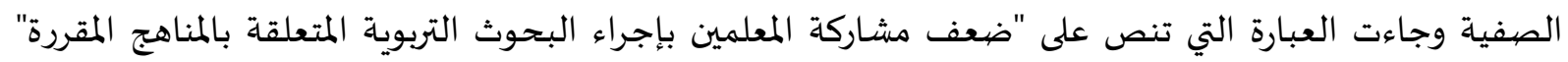

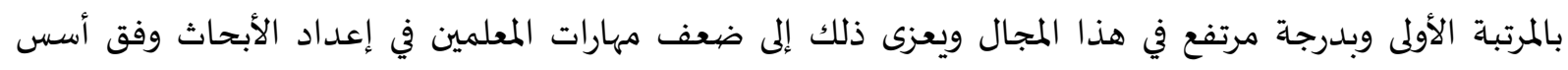

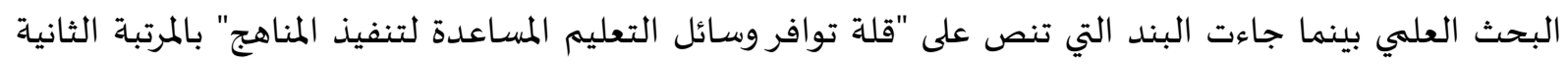

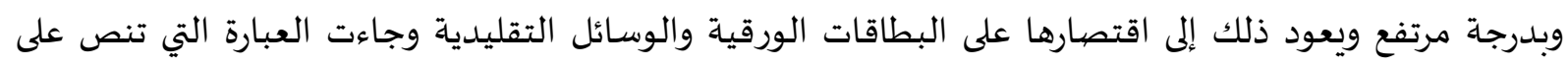

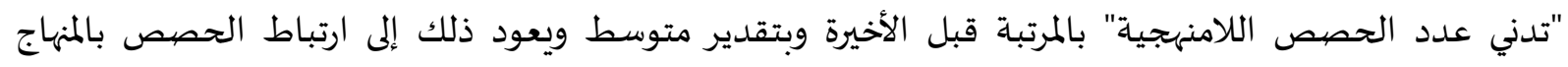

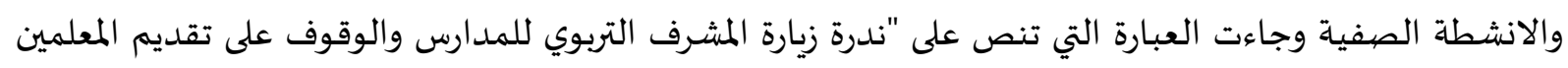

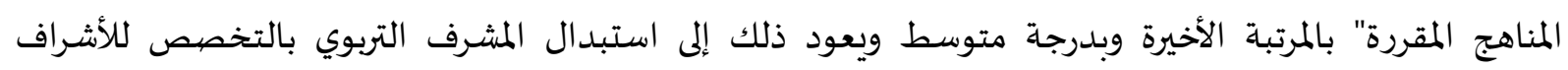

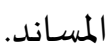

\section{رابعاً: مجال المعوقات ذات صللة بالتجهيزات التكنولوجية للمدرسة}

أشارت النتائج إلى أن المجال الذي يتعلق بمعوقات "التجهيزات التكنولوجية للمدرسة" حصات حصل على المرتبة

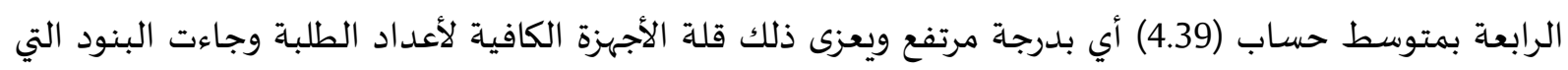

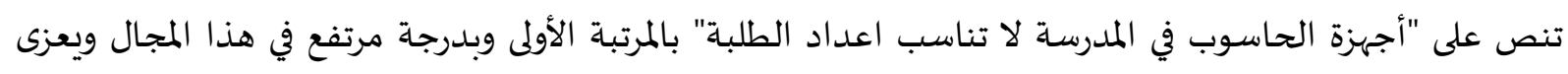

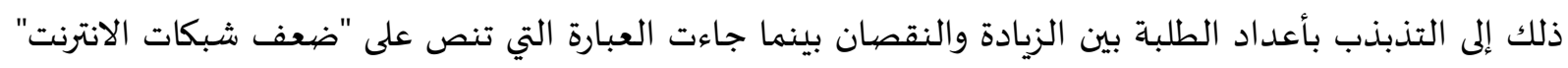

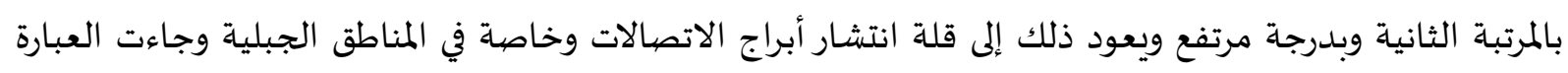

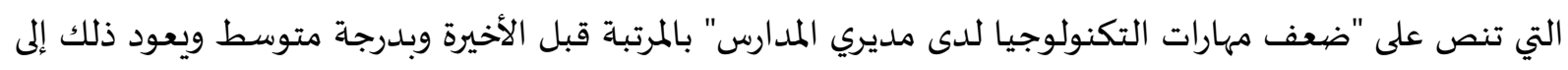

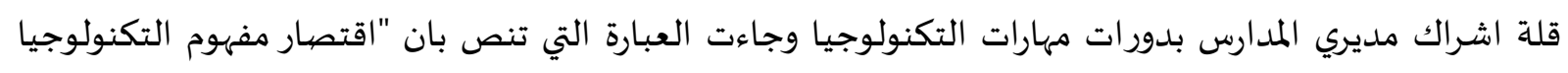

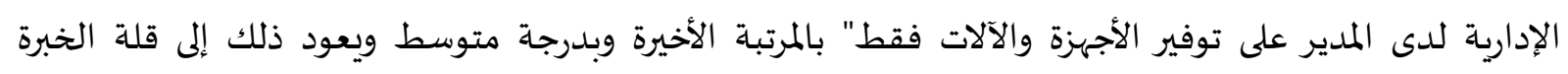
بتوظيف التطبيقات التكنولوجية مثل تطبيق (التيمز).

خامساً: مجال المعوقات التي ذات صلة بالطلبة

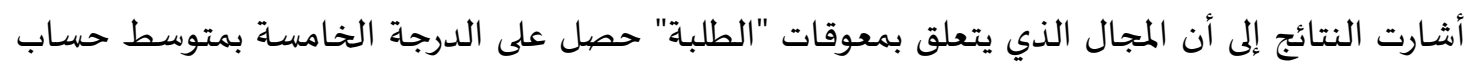

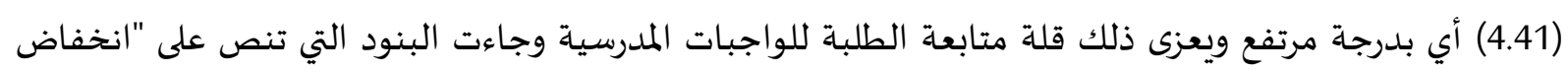

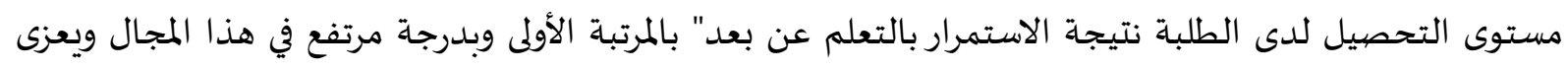

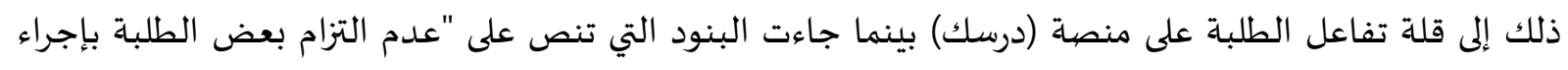

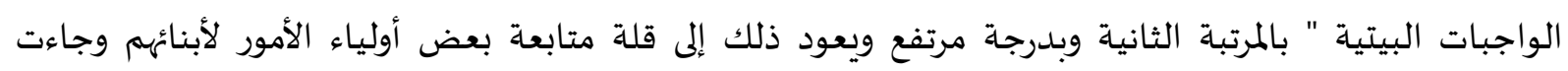

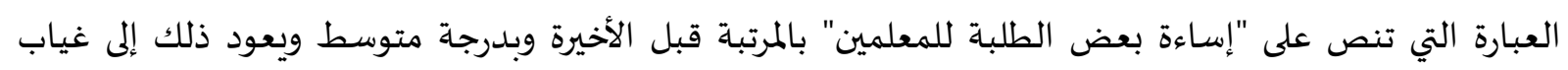


الوعي الاجتماعي والثقافي والتربوي لفئة قليلة من المجتمع المحلي وجاءت العبارة التي تنص على "إسـاءة بعض المعلمين

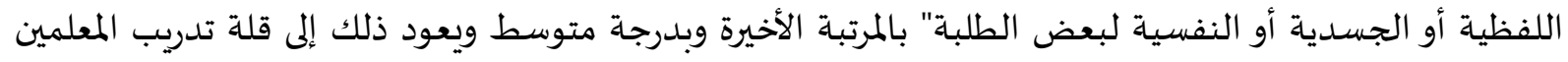
على مهارات التواصل والاتصال الاجتماعية والتعامل مع مراحل متعددة وخاصة مرحلة المعلة المراهقة.

مناقشة نتائج السؤال الثاني: هل توجد فروق ذات دلالة إحصائية عند مستوى الدلالة (الأل0.

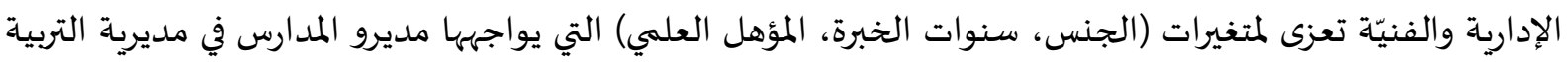

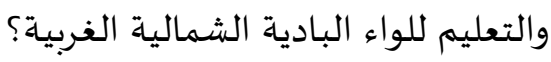

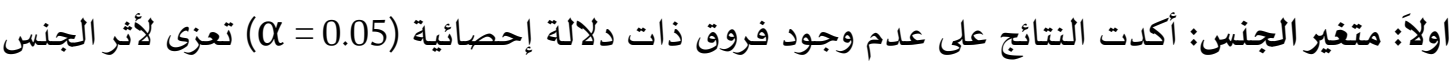

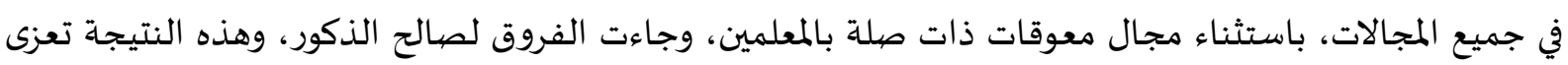

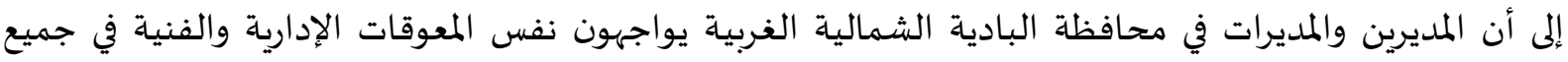

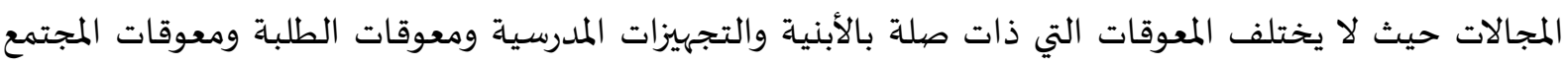

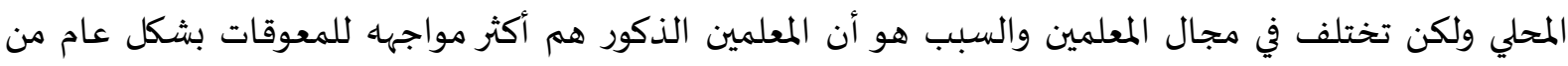

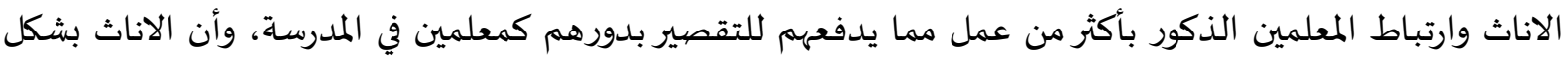

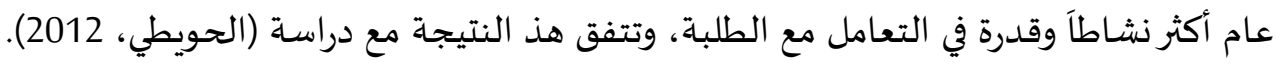

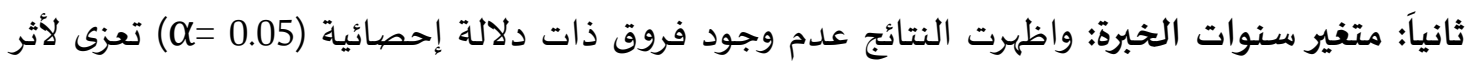

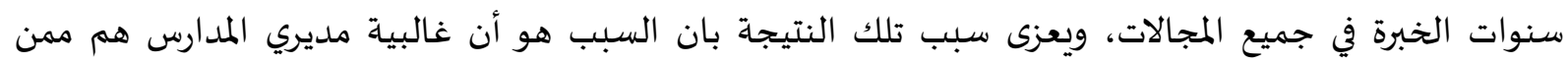

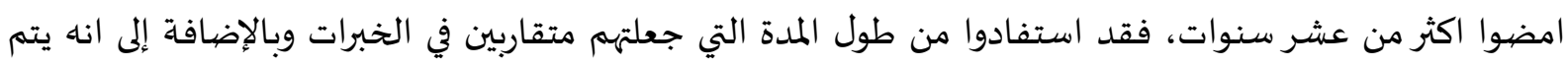

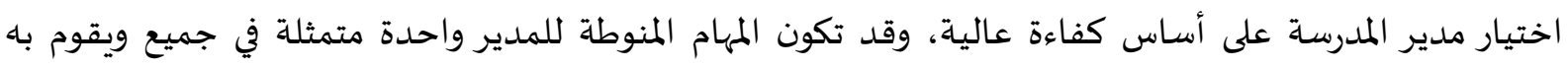

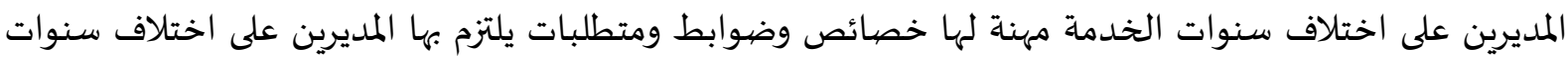
خدمتهم وتتفق مع دراسة (أبو علي، 2010). ثالثاً: متغير المؤهل العلمي: واظهرت النتائج عدم وجود فروق ذاتئ دات دلالة إحصائية (م=0.05) تعزى لأثر

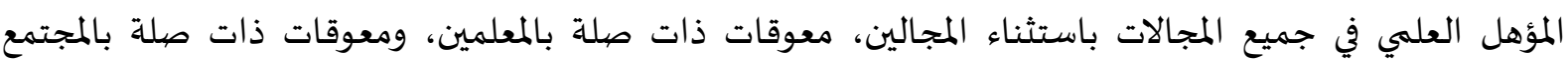

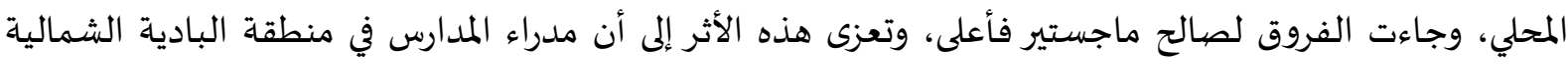

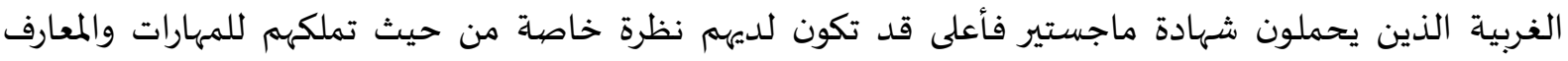

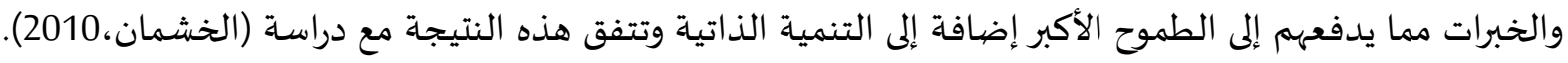
مناقشـة نتائج السؤال الثالث: ما مقترحاتكم لمعالجة المعوقات الإدارية والفنيّة التي يواجهها مديري المدارس في

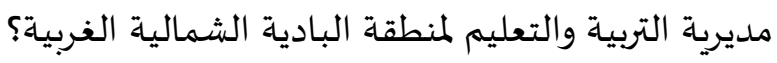

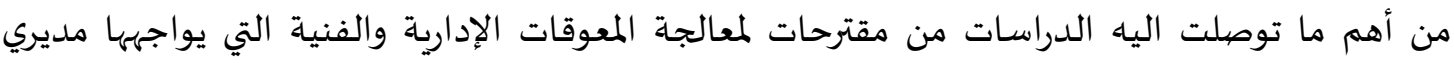
المدارس في مديرية التربية والتعليم للواء البادية الشمالية الغربية هي كالتالي: 1- - تعين مساعدين للأمور الفنية والإدارية. 2- - 2- - التنمية المهنية

3- توفير الحواسيب الكافية للمدرسة والمتابعة الاشرافية للمعلمين 4- توفر بنية تحتية صحيحة، وتوفر مختبرات تحاكي وتواكب الانفجار المعرفي. 
5- توفير أكبر قدر من الاهتمام لعناصر التكنولوجيا التي يطالبون بها لتحقيق النتاجات المطلوبة، وتوفير معلمين مختصين دايمين وغير مشتركين مع مدارس أخرى.

التوصيات والمقترحات. 1- الاهتمام من قبل القائمين على إدارة التعليم في مواجهة المعوقات الإدارية والفنية، وتنمية الموارد البشرية،

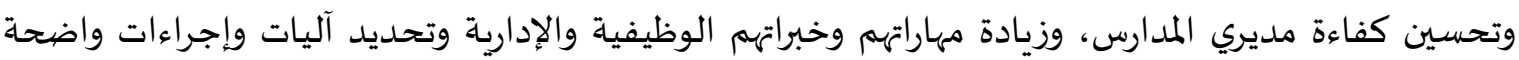
ومرنة لإدارة المعوقات الإدارية والفنية. 2- مشاركة الموظفين والجهات المعنية في اقتراح حلول للمعوقات الإدارية والفنية عن طريق الاستعانة بآرائهم، لإإيجاد سبل للتغلب على المعوقات الإدارية الفنية. 3- مناقشة الكادر الوظيفي في إيجاد حلول للمعوقات التي تواجههم اثناء العمل. 4- - تذليل المعوقات التي تواجه الكادر الإداري والوظيفي.

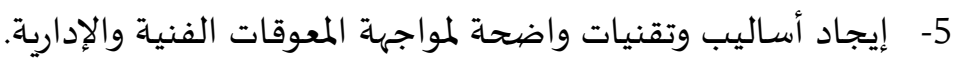
6- الاستمرارية والديمومة الشاملة اثناء المراجعة العملية.

- ـ إبراهيم، محمد (2010). المعوقات الإدارية التي تواجه مديري مدارس منطقة الثالثة في محافظة اربد من وجهة

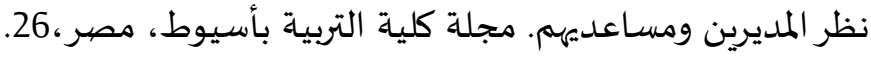
- أبو سيدو، وفاء (2009) معوقات مدرات مدارس البنات الأساسية العليا الحكومية والمدارس الإعدادية بوكالة الغوث بمحافظات غزة (رسالة ماجستير غبر منشورة)، الجامعة الإسلامية، غزة.

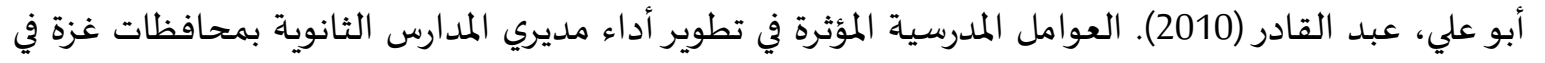

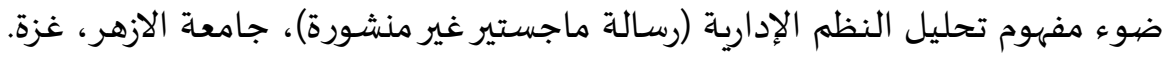

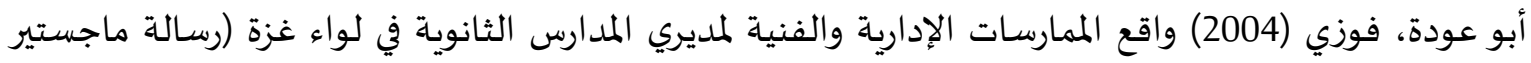
غير منشورة)، جامعة الأزهر، غزةد. - - احمد، احمد إبراهيم (2001) الإدارة المدرسية في الألفية الثالثة، الإسكندرية، مكتبة المعارف الحديثة.

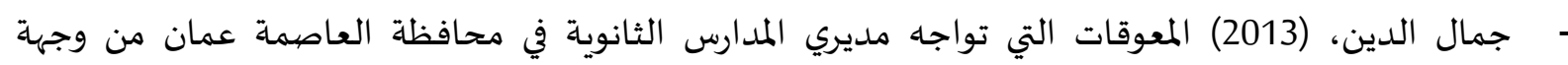

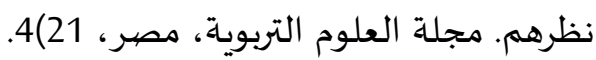

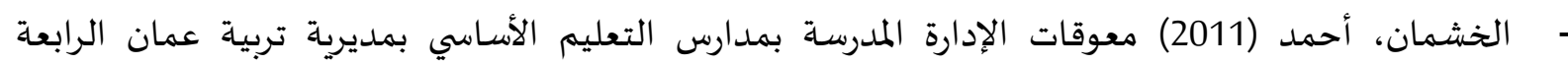

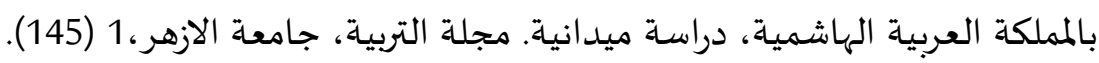

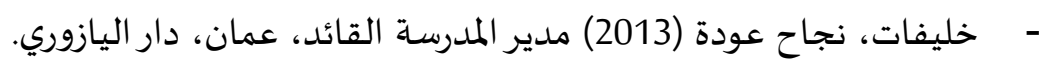

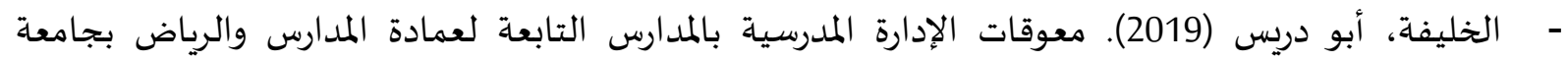

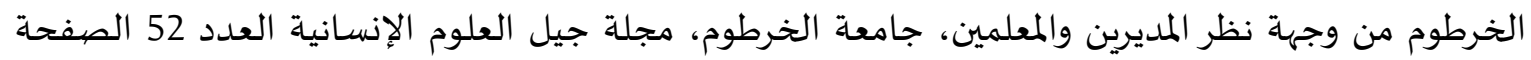


رضوان، عماد (2009) معوقات الإدارة المدرسية في المداس الثانوية الخاصة بالقاهرة، (رسالة ماجستير غير

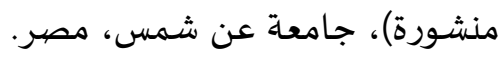

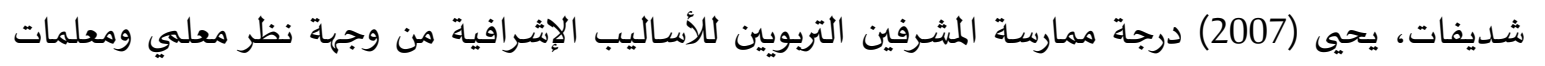

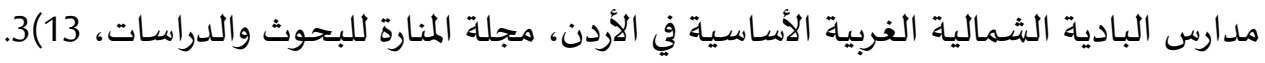

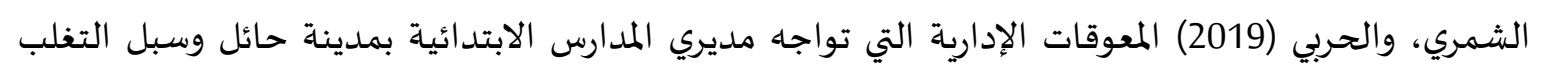
عليها من وجهة نظرهم، المجلة العربية للعلوم التربوية والنفسية.

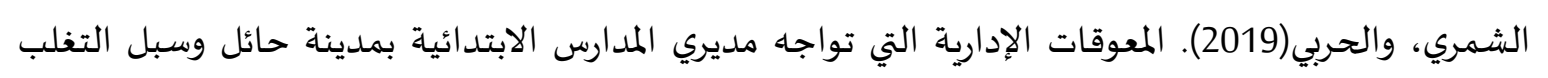
عليها من وجهة نظرهم، المجلة العربية للعلوم التربوية والنفسية. الصلوي، أنور (2005) المعوقات التي تواجه الإدارة المدرسية في مرحلة التعليم الثانوي في مدينة تعز بلهيه باليمن.

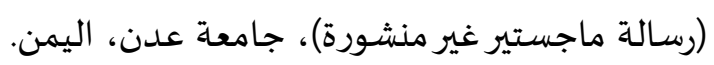

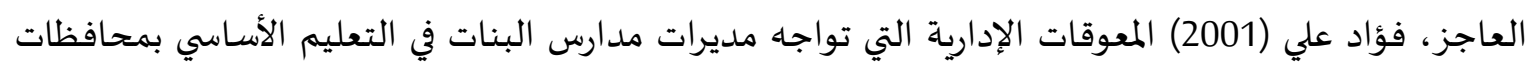

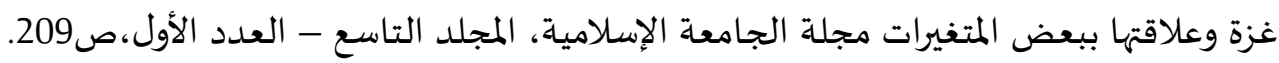

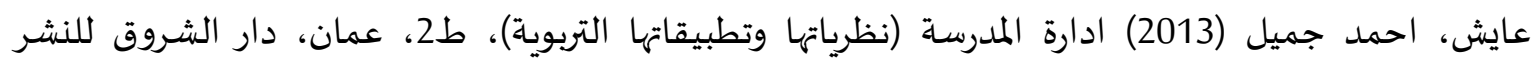
والتوزع.

عساف، محمود (2005)، واقع الإدارة المدرسية في محافظة غزة في ضوء معايير الإدارة الاستراتيجية. (رسالة ماجستير غير منشورة)، الجامعة الإسلامية، غزة. عطوي، جودت (2010) الإدارة المدرسية الحديثة مفاهيمها النظرية وتطبيقاتها العملية. (د. ط)، الأردن: دار

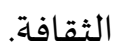

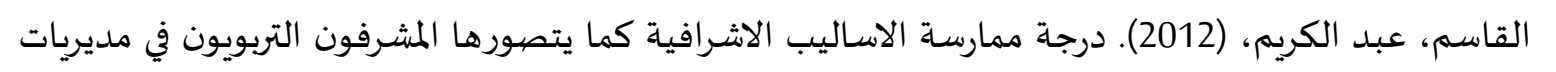
التربية والتعليم في محافظات شمال فلسطين، مجلة جامعة القدس المفتوحة للأبحاث والدراسات، فلسطين،

كناعنة نظير وسلامة، كايد (2017). المعوقات التربوية التي تواجه المدارس الثانوية كما يراها المشرفين التربويين

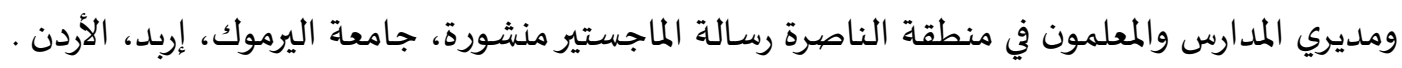

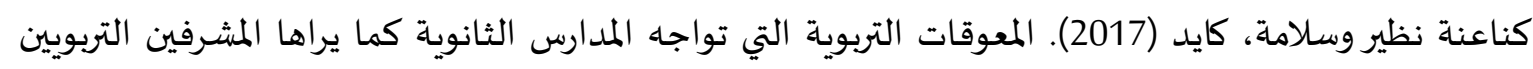

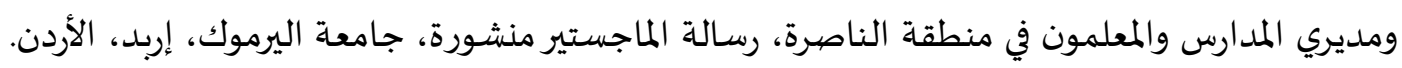

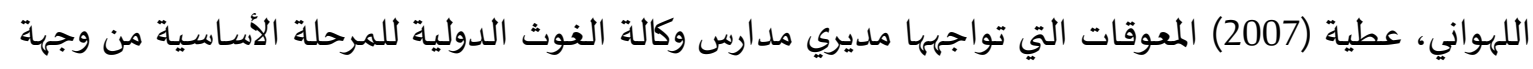
نظر مديري هذه المدارس ومعلمها في محافظات شمال فلسطين، (رسالة ماجستير غير منشورة)، جامعة النجاح الوطنية، فلسطين. الهباش، أسامة (2002) المعوقات التي تواجه المديرية الجدد في مدارس محافظات غزة وسبل مواجهتها (رسالة ماجستير غير منشورة)، الجامعة الإسلامية، غزة.

ثانياً- المراجع بالإنجليزية:

- Perter, S. (2004) Planning procedures and leadership rale of the principal in professional development school (phd) Dissertatio Ball State University. 